\title{
Climatic Region and Vine Structure: Effect on Pinotage Wine Phenolic Composition, Total Antioxidant Capacity and Colour*
}

\author{
D. de Beer ${ }^{1}$, E. Joubert ${ }^{1,2},{ }^{*}$, J. Marais $^{2}$, D. van Schalkwyk ${ }^{2}$ and M. Manley ${ }^{1}$
}

(1) Department of Food Science, Stellenbosch University, Private Bag X1, 7602 Matieland (Stellenbosch), South Africa; DBeerD@arc.agric.za,mman@sun.co.za

(2) ARC Infruitec-Nietvoorbij (Fruit, Vine and Wine Institute of the Agricultural Research Council), Private Bag X5026, 7599 Stellenbosch, South Africa; JoubertL@arc.agric.za, MaraisJ@arc.agric.za, VSchalkwykD@arc.agric.za

Submitted for publication: April 2006

Accepted for publication: June 2006

Key words: Antioxidants, climatic region, free radical scavenging, phenolic compounds, vine structure.

\begin{abstract}
The phenolic composition, total antioxidant capacity (TAC) and colour of Pinotage wines of the 2001, 2002 and 2003 vintages were investigated, using spectrophotometric, high-performance liquid chromatography (HPLC), free radical scavenging and objective colour analyses. Grapes were harvested from grapevines in three climatic regions ranging from cool to warm, with bush (20- and 30-cm trunk height) and trellised (30- and 60-cm trunk heights) vine treatments, on several vineyard sites in each climatic area. Climatic region had a significant effect on the content of several phenolic compounds; the concentration of anthocyanin monoglucosides, flavonols, flavan-3-ols and tartaric acid esters of hydroxycinnamic acids generally increased as the climatic region becomes cooler, while concentrations of acylated derivatives and free hydroxycinnamic acids decreased. Wines made from bush vines contained higher concentrations of flavonols, gallic acid and flavan-3-ols than those from trellised vines, but lower concentrations of some anthocyanin monoglucosides and acylated derivatives, as well as non-coloured polymers. These trends resulted in differences in TAC and objective colour parameters, although the different vintages did not show the same trends in all cases. More vintages should therefore be investigated to clarify these effects. Wines from the cool climatic regions and from bush vines were generally darker coloured, with higher TAC than those from the warm climatic regions and bush vines, respectively. High TAC, therefore, coincided with higher colour quality. Variations in TAC were partly explained by trends for individual phenolic compounds, although unknown compounds played a major role.
\end{abstract}

\section{INTRODUCTION}

Grape phenolic composition is greatly affected by climatic conditions and vine management practices (Jackson \& Lombard, 1993). A wide variety of systems have been developed to describe the viticultural potential of a climatic region (inter alia, Amerine \& Winkler, 1944; Smart \& Dry, 1980; Huglin, 1986). In the South African context, the Western Cape viticultural regions have been divided by Le Roux (1974) according to the heat summation model of Amerine \& Winkler (1944), as well as by De Villiers et al. (1996), according to the mean temperature of the warmest month model of Smart \& Dry (1980), using the mean February temperatures. High temperatures have been reported to result in lower anthocyanin (Kliewer, 1970; Bergqvist et al., 2001; Spayd et al., 2002) and total phenol (Bergqvist et al., 2001) berry content compared to lower temperatures.

Vine management practices modify the canopy microclimate in order to control sunlight exposure and fruit temperature during berry maturation. Sunlight exposure generally results in higher juice $\mathrm{pH}$, total soluble solids, anthocyanin, flavonol and phenolic contents, while titratable acidity, malate content, and berry mass are lower (Kliewer, 1970; Crippen \& Morrison, 1986; Reynolds et al.,
1986; Spayd et al., 2002; Downey et al., 2004). In warm climates, however, a high degree of sunlight exposure negatively affects the anthocyanin content of red grapes (Haselgrove et al., 2000).

Generally, Pinotage vines grown in South Africa are headtrained and spur-pruned (bush vines), or trained to a bilateral horizontal cordon and spur-pruned with upward vertical shoot positioning (trellised vines). Winemakers and producers speculate whether bush vines or trellised vines are preferable for making high-quality Pinotage wines. Vine structure was demonstrated to affect the phenolic composition of berry skins (Tamborra et al., 2003). It is also not clear whether cultivation of Pinotage under cool or warm climatic conditions is best for obtaining high quality wine. It is expected that these factors will also affect the antioxidant capacity of Pinotage wines. No research to show the effect of climatic region or vine management practices on the antioxidant capacity of red wines has been reported. Consequently, the aim of this project was to determine the effect of vine structure (training system and trunk height), as well as climatic region, on the phenolic composition, total antioxidant capacity (TAC) and colour of Pinotage wines from the Western Cape.

\footnotetext{
* Part of work submitted for a PhD in Food Science at Stellenbosch University, 2006.

** Corresponding author: JoubertL@arc.agric.za,

Acknowledgements: André Schmidt is thanked for technical assistance. Winetech, the National Research Foundation (NRF) and the Technology and Human Resources for Industry Programme (THRIP) are thanked for financial support. Frikkie Calitz of the Biometry Unit, ARC Infruitec-Nietvoorbij, is thanked for statistical analysis of data.
} 


\section{MATERIALS AND METHODS}

\section{Viticultural treatments and wine-making procedure}

Vineyard sites were located in three climatic regions of the coastal region (Western Cape, South Africa), differentiated according to average February temperatures using macro climatic weather station data, as described by De Villiers et al. (1996) (see Fig. 1): region II (av February temperature $=19.0-20.9^{\circ} \mathrm{C}$ ), region III (av February temperature $=21.0-22.9^{\circ} \mathrm{C}$ ) and region IV (av February temperature $=23.0-24.9^{\circ} \mathrm{C}$ ). Temperature data taken during February 2004 and 2005 using mini data loggers (Tinytag Plus TGP-1500, Gemini Data Loggers (UK) Ltd., Chichester, UK) at individual vineyards were used to confirm the allocation of vineyard sites on the border between regions to a specific region (data not shown). The seven vineyard sites in climatic region II were located in the Darling (1 site), Stellenbosch (higher than 300-m above sea level) (5 sites) and Hemel and Aarde Valley (Hermanus) (1 site) regions. In climatic region III the six vineyard sites were located in the Kuils River (2 sites) and Stellenbosch (lower than 300-m above sea level) (4 sites) regions. In climatic region IV the experimental sites were located in the Darling (1 site), Riebeeck-Wes (1 site) and Wellington/Paarl (5 sites) regions. All vines were Pinotage clone PI 48 grafted onto 99 Richter rootstock. Vine distances, row orientation, cover crop, nutrition and irrigation were not standardised as sites had to reflect normal viticultural practices in a region. Vine structure treatments were bush (head-trained and spur-pruned) and trellised (trained to a bilateral horizontal cordon and spur-pruned with upward vertical shoot positioning) vines with main trunk heights of 20 or $30 \mathrm{~cm}$ for bush vines and 30 or $60 \mathrm{~cm}$ for trellised vines. Canopy management was applied for all vines, namely suckering to two bearer shoots per bearer, suckering between bearers and leaf removal at berry set to three-leaf layers to obtain an optimal canopy density (Smart \& Robinson, 1991; Hunter, 1999). All combinations of these treatments were carried out on each of the vineyard sites during the 2000/2001, 2001/2002 and 2002/2003 growing seasons.

The sugar content of the grapes, when harvested, ranged between 24 and $26^{\circ} \mathrm{B}$, with $14 \%, 14 \%$ and $16 \%$ of the treatments harvested outside of this range during 2001, 2002 and 2003, respectively. Harvesting was performed manually by the same pickers at each site. Different vineyard sites in the same climatic region represented repetitions. Wines were produced with 20 to $30 \mathrm{~kg}$ of grapes per treatment at the experimental cellar of ARC Infruitec-Nietvoorbij (South Africa) according to the basic winemaking protocol with no wood contact (described in De Beer et al., 2006). After bottling, the wines were stored at $15^{\circ} \mathrm{C}$. Eight months after production, aliquots of each wine were frozen at $20^{\circ} \mathrm{C}$ to prevent further phenolic changes until analyses could be carried out. Samples were analysed immediately after defrosting.

\section{Chemicals and phenolic reference standards}

2,2'-Azino-di-(3-ethylbenzo-thialozine-sulphonic acid) (ABTS) was obtained from Boehringer Mannheim GmbH (Mannheim, Germany) and high-performance liquid chromatography (HPLC) grade acetonitrile and glacial acetic acid from Riedel-de Haën (Seelze, Germany). Phosphoric acid (HPLC grade) and 4-dimethylamino-cinnamaldehyde (DAC) were obtained from Fluka (Buchs, Switzerland) and Folin-Ciocalteau's phenol reagent from Merck
(Darmstadt, Germany). Potassium persulphate $\left(\mathrm{K}_{2} \mathrm{~S}_{2} \mathrm{O}_{8}\right)$ was obtained from Sigma Chemical Co. (St. Louis, MO, USA) and 6hydroxy-2,5,7,8-tetra-methylchroman-2-carboxylic acid (Trolox) from Aldrich Chemical Co. (Gillingham, UK). Methanol (AR), concentrated hydrochloric acid (AR), sodium chloride (AnalAR) and sodium hydroxide (AnalAR) were obtained from SaarChem (Midrand, South Africa). Phenolic reference standards included gallic acid, (+)-catechin and quercetin-3-rhamnoside (Q-3-Rham) from Sigma; caffeoyltartaric acid from Chromadex (Santa Ana, CA, USA); caffeic acid, quercetin and kaempferol from Fluka; procyanidin B1, quercetin-3-Glc and myricetin from Extrasynthese (Genay, France); and delphinidin-3-Glc, peonidin-3-Glc, petunidin-3-Glc and malvidin-3-Glc from Polyphenols AS (Sandnes, Norway). Water used in the experiments was purified and deionised with a Modulab water purification system (Separations, Cape Town, South Africa), except for preparation of HPLC mobile phases where de-ionised water was further treated using a Milli-Q academic water purifier (Millipore, Bedford, MA, USA).

\section{Spectrophotometric analysis of phenolic composition}

Pinotage wines from all vintages were subjected to spectrophotometric analysis of the major phenolic groups described below.

The total phenol content of wines was determined using the method of Singleton and Rossi (1965), scaled down to a final reaction volume of $5 \mathrm{~mL}$. Gallic acid was used as standard and results were expressed as $\mathrm{mg}$ gallic acid equivalents/L.

The anthocyanin content of wines was estimated using the $\mathrm{pH}$ shift method of Ribéreau-Gayon \& Stonestreet (1965), adapted by De Beer et al. (2003). A pH 4.9 buffer was used instead of a pH 3.5 buffer. Anthocyanins were quantified as mg malvidin-3glucoside equivalents/L.

The total flavan-3-ol content (DAC) of wines was measured using the method of McMurrough \& McDowell (1978), as adapted by de Beer et al. (2003). (+)-Catechin was used as a standard and the results expressed as $\mathrm{mg}$ catechin equivalents/L.

Spectrophotometric measurements were made in disposable polystyrene $2.5-\mathrm{mL}$ macro cuvettes with $1-\mathrm{cm}$ path length using a Beckman DU-65 UV/Vis spectrophotometer (Beckman Instruments Inc., Fullerton, CA, USA).

\section{HPLC analysis of phenolic composition}

Individual phenolic compounds, as well as coloured and noncoloured polymers detected at 520 and $280 \mathrm{~nm}$, respectively, in Pinotage wines from the 2002 and 2003 vintages were quantified using an HPLC method (Peng et al., 2002), modified as described by De Beer et al. (2006). Polymers included polymeric phenolic compounds with five or more subunits consisting of anthocyanins and flavan-3-ols for coloured polymers and only flavan-3-ols for non-coloured polymers. The HPLC apparatus used was a Waters LC Module I equipped with a Waters 2996 photodiode array detector using Millenium ${ }^{32}$ version 4.0 software (Waters, Milford, MA, USA). Separation was achieved on a PolymerX column (250 x $4.6 \mathrm{~mm}, 100 \AA$ pore size, 5- $\mu \mathrm{m}$ particle size) from Phenomenex (Torrance, CA, USA). A PRP1 guard cartridge $(20 \times 2.3 \mathrm{~mm})$ packed with a similar material (Hamilton, Reno, NV, USA) and a PEEK PAT frit $(5 \mathrm{~mm})$ were used to protect the analytical column. Wines were filtered using $0.45-\mu \mathrm{m}$ Millex-HV hydrophilic PVDF 33-mm syringe-tip filter devices (Millipore) before automated duplicate injections of $20 \mu \mathrm{L}$ each. The column was held at $30^{\circ} \mathrm{C}$ 


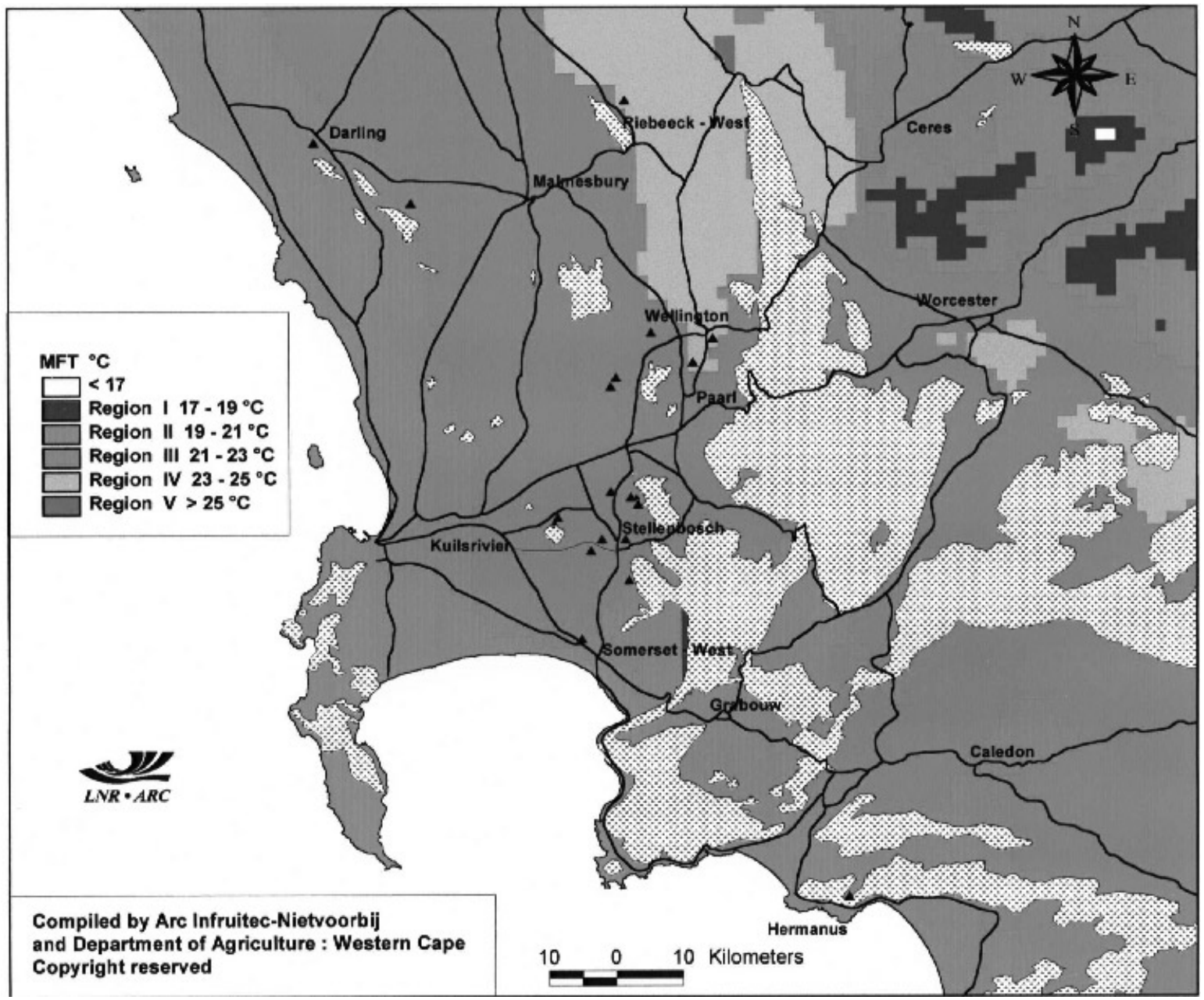

FIGURE 1

Division of Western Cape Pinotage cultivation areas into climatic regions on the basis of mean February temperatures (MFT) as described by De Villiers et al. (1996) [triangles indicate experimental vineyard sites].

during the run and the flow-rate was $0.9 \mathrm{~mL} / \mathrm{min}$. The mobile phases used were: $1.5 \%(\mathrm{v} / \mathrm{v})$ aqueous phosphoric acid (A) and $1.5 \%$ (v/v) phosphoric acid in acetonitrile/water (80/20) (B).

\section{ABTS radical cation scavenging assay}

The total antioxidant capacity (TAC) of Pinotage wines from all vintages was measured $\left(\mathrm{TAC}_{\mathrm{M}}\right)$ using the $\mathrm{ABTS}^{++}$scavenging assay (Re et al., 1999). The content of individual phenolic compounds as measured using HPLC and their experimental Trolox equivalent antioxidant capacity (TEAC) values (reported in De Beer et al., 2006) were used to calculate the theoretical TAC $\left(\mathrm{TAC}_{\mathrm{CAL}}\right)$. The remaining TAC $\left(\mathrm{TAC}_{\mathrm{R}}\right)$ is the difference between $\mathrm{TAC}_{\mathrm{M}}$ and $\mathrm{TAC}_{\mathrm{CAL}}$. Analysis and calculations were carried out as described by De Beer et al. (2006).

\section{Objective colour parameters}

A Colorgard System 2000 Colorimeter (BYK-Gardner, Geretsried, Germany) was used to obtain the objective colour parameters of the undiluted Pinotage wines from all vintages in transmittance mode with a 5-mm fixed path length optical cell. The colorimeter was calibrated before use with a non-diffusing black reflectance standard (BYK-Gardner, Geretsried, Germany) to obtain a zero calibration. Objective colour measurements were taken less than one hour after opening of a wine bottle to minimise colour changes. The CIELab parameters, namely $a^{*}$ (red/green chromaticity), $b^{*}$ (yellow/blue chromaticity) and $L^{*}$ (lightness), were measured using the CIE 1931 standard colorimetric observer under illuminant $\mathrm{C}$ (geometry is $45^{\circ}$ illumination and $0^{\circ}$ viewing). The $h^{*}$ (hue angle; ${ }^{\circ}$ ) and $C^{*}$ (chroma) were calculated as follows:

$$
\begin{aligned}
& h^{*}=\tan ^{-1}\left(b^{*} / a^{*}\right) \\
& C^{*}=\left[\left(a^{*}\right)^{2}+\left(b^{*}\right)^{2}\right]^{1 / 2}
\end{aligned}
$$

Names for hues were adapted from Gonnet (1999) based on the $h^{*}$ values. Hue angle values of $0^{\circ}, 7.5^{\circ}, 15^{\circ}, 22.5^{\circ}, 30^{\circ}, 37.5^{\circ}$ and $45^{\circ}$ correspond to magenta, red-magenta, magenta-red, red, orange-red, red-orange and orange, respectively.

\section{Statistical analysis}

Analysis of variance was performed on the means for climatic regions and vine structure treatments to determine whether significant differences occurred. The Student $t$-LSD test $(\mathrm{P}<0.05)$ was used to determine the statistical differences between means. Covariance analysis was also performed with grape sugar content $\left({ }^{\circ} \mathrm{B}\right)$ as covariate. Analysis of variance, difference testing and covariance analysis were done using the SAS version 8 software 
package (SAS Institute Inc., Cary, NC). In cases where the covariate had a significant $(\mathrm{P}<0.05)$ effect, the adjusted means were compared. Where no interactions between different factors were observed, or where treatments did not differ significantly, data were pooled. Canonical discriminant analysis of data obtained for wines produced during 2002 and 2003, using forward stepwise variable selection, was performed to distinguish between climatic regions and vine structure treatments. Pearson product moment correlation coefficients between parameters and their P-values were calculated. Canonical discriminant analysis and calculation of correlation coefficients were done using the STATISTICA 6 software package (StatSoft, Inc., Tulsa, OK).

\section{RESULTS}

The average grape sugar content did not differ significantly between the vintages (Table 1).

\section{Vintage-related variations}

Some vintage-related variations were observed in terms of the phenolic composition and TAC of Pinotage wines (Tables $1 \& 2$ ). The climatic region and vine structure treatments had varying effects depending on vintage.

Spectrophotometric determination of phenolic content showed significant differences between wines from different vintages (Table 1). Wines of the 2001 vintage had the highest total phenol content, as well as the highest monomeric, polymeric and total anthocyanin content ( $\mathrm{pH}$ shift). The 2002 wines had the lowest polymeric and total anthocyanin content ( $\mathrm{pH}$ shift), while the 2003 wines had the lowest total flavan-3-ol content (DAC).

Only the individual phenolic compounds for the 2002 and 2003 wines were quantified (Table 2). Some flavonol compounds, namely quercetin-3-galactoside (Gal), myricetin, kaempferol and isorhamnetin, were only detected in some wines. Of the 63 wines produced during 2002, measurable amounts of quercetin-3-Gal, kaempferol and isorhamnetin were present in 18, 38 and 47 wines, respectively, while of the 77 wines produced in 2003 measurable amounts of quercetin-3-Gal, myricetin and isorhamnetin were present in 23, 25 and 36 wines, respectively. Values for these compounds in the respective vintages will not be reported, as statistical analysis was not possible. The total flavonol content, however, refers to the sum of all flavonols.

Large vintage-related variations were found for the contents of individual phenolic compounds (Table 2). The 2002 wines had significantly higher concentrations of most phenolic compounds compared to the 2003 wines, except for vitisin A, malvidin-3-pcoumaroylglucoside (Glc-Coum), quercetin-3-Glc, gallic acid, caftaric acid and non-coloured polymers, which did not differ significantly, and malvidin-3-Glc, peonidin-3-Glc-Ac, malvidin-3Glc-Ac, coloured polymer (HPLC), an unknown flavonol and quercetin-3-rhamnoside (Rham), which were significantly lower.

The TAC of the wines varied significantly between vintages, with the $\mathrm{TAC}_{\mathrm{M}}$ highest during 2002 and lowest during 2001 (Table 1). The $\mathrm{TAC}_{\mathrm{CAL}}$ and $\mathrm{TAC}_{\mathrm{R}}$ were lower for the 2003 wines than the 2002 wines.

For each vintage, the total phenol content correlated well $(\mathrm{P}<0.001)$ with the $\mathrm{TAC}_{\mathrm{M}}$ values of the wines of that particular vintage, while a weaker, but still significant correlation $(\mathrm{P}<0.001)$ was observed when data of the three vintages were pooled (Fig. 2 and Table 3). Similar trends were observed for the correlations $(\mathrm{P}<0.001)$ between the total flavan-3-ol content (DAC) and the $\mathrm{TAC}_{\mathrm{M}}$ values for the different vintages, although

\section{TABLE 1}

Vintage-related variation in sugar content of grapes, as well as the phenolic composition (measured spectrophotometrically), antioxidant capacity and objective colour parameters of the 2001, 2002 and 2003 Pinotage wines.

\begin{tabular}{|c|c|c|c|}
\hline & $2001^{\mathrm{a}}$ & $2002^{\mathrm{a}}$ & $2003^{a}$ \\
\hline Sugar content ${ }^{\mathrm{b}}$ & $25.0 \mathrm{a}^{\mathrm{c}}( \pm 0.1)^{\mathrm{d}}$ & $24.9 \mathrm{a}( \pm 0.1)$ & $25.0 \mathrm{a}( \pm 0.1)$ \\
\hline \multicolumn{4}{|l|}{ Phenolic composition } \\
\hline Monomeric anthocyanins ${ }^{\mathrm{f}}$ & $494.3 \mathrm{a}( \pm 8.2)$ & $443.5 \mathrm{~b}( \pm 7.4)$ & $462.5 \mathrm{~b}( \pm 7.4)$ \\
\hline Polymeric anthocyanins ${ }^{\mathrm{f}}$ & $130.6 \mathrm{a}( \pm 3.4)$ & $54.1 \mathrm{c}( \pm 1.5)$ & $64.7 \mathrm{~b}( \pm 2.0)$ \\
\hline Total anthocyanins ${ }^{\mathrm{f}}$ & $624.9 \mathrm{a}( \pm 11.0)$ & $497.5 \mathrm{c}( \pm 8.4)$ & $527.2 \mathrm{~b}( \pm 9.2)$ \\
\hline \multicolumn{4}{|l|}{ Antioxidant capacity } \\
\hline $\mathrm{TAC}_{\mathrm{M}}^{\mathrm{h}}$ & $11.84 \mathrm{c}( \pm 0.28)$ & $14.87 \mathrm{a}( \pm 0.28)$ & $13.36 \mathrm{~b}( \pm 0.24)$ \\
\hline $\mathrm{TAC}_{\mathrm{CAL}}{ }^{\mathrm{i}}$ & na & $2.13 \mathrm{a}( \pm 0.03)$ & $1.97 \mathrm{~b}( \pm 0.02)$ \\
\hline $\mathrm{TAC}_{\mathrm{R}}{ }^{\mathrm{j}}$ & na & $12.84 \mathrm{a}( \pm 0.27)$ & $11.35 \mathrm{~b}( \pm 0.23)$ \\
\hline \multicolumn{4}{|l|}{ Objective colour parameters } \\
\hline$b^{* \mathrm{o}}$ & $14.58 \mathrm{a}( \pm 0.34)$ & $15.08 \mathrm{a}( \pm 0.41)$ & $14.38 \mathrm{a}( \pm 0.33)$ \\
\hline
\end{tabular}

${ }^{\mathrm{a}}$ means taken over all climatic regions and vine structure treatments for a specific vintage; $\mathrm{b}{ }^{\circ} \mathrm{B} ;{ }^{\mathrm{c}}$ different letters in a row denote significant differences $(\mathrm{P}<0.05)$; ${ }^{\mathrm{stan}}$ dard error of mean; ${ }^{\mathrm{e}} \mathrm{mg}$ gallic acid equivalents/L; ${ }^{\mathrm{f}} \mathrm{mg}$ malvidin-3-glucoside equivalents/L; ${ }^{\mathrm{g}} \mathrm{mg}(+)$-catechin equivalents/L; ${ }^{\mathrm{h}}$ total antioxidant capacity in mM Trolox equivalents as measured; ${ }^{i}$ total antioxidant capacity in $\mathrm{mM}$ Trolox equivalents as calculated from the content of monomeric phenolic compounds and their Trolox equivalent antioxidant capacity; ${ }^{\mathrm{j}} \mathrm{TAC} \mathrm{R}=\mathrm{TAC} \mathrm{M}-\mathrm{TAC} \mathrm{CAL}_{\mathrm{C}} ;{ }^{\mathrm{k}}$ chroma; ${ }^{1}$ hue angle $\left({ }^{\circ}\right) ;{ }^{\mathrm{m}}$ lightness; ${ }^{\mathrm{n}}$ red/green chromaticity; ${ }^{\mathrm{o}}$ yellow/blue chromaticity; na $=$ not available. 
TABLE 2

Vintage-related variation in phenolic composition ${ }^{\mathrm{a}}$ (measured by HPLC) of the 2002 and 2003 Pinotage wines.

\begin{tabular}{|c|c|c|}
\hline Compound/Phenolic group & 2002 & 2003 \\
\hline \multicolumn{3}{|l|}{ Anthocyanins } \\
\hline Delphinidin-3-Glc & $16.82 \mathrm{a}^{\mathrm{b}}( \pm 0.60)^{\mathrm{c}}$ & $13.50 \mathrm{~b}( \pm 0.54)$ \\
\hline Petunidin-3-Glc & $24.30 \mathrm{a}( \pm 0.60)$ & $21.21 \mathrm{~b}( \pm 0.58)$ \\
\hline Peonidin-3-Glc & $9.70 \mathrm{a}( \pm 0.39)$ & $5.71 \mathrm{~b}( \pm 0.32)$ \\
\hline Malvidin-3-Glc & $211.21 \mathrm{~b}( \pm 4.30)$ & $228.88 \mathrm{a}( \pm 3.10)$ \\
\hline Delphinidin-3-Glc-Ac ${ }^{\mathrm{d}}$ & $6.20 \mathrm{a}( \pm 0.18)$ & $4.59 \mathrm{~b}( \pm 0.18)$ \\
\hline Vitisin $A^{d}$ & $6.29 \mathrm{a}( \pm 0.38)$ & 5.30 a $( \pm 0.39)$ \\
\hline Petunidin-3-Glc-Ac ${ }^{d}$ & $6.26 \mathrm{a}( \pm 0.17)$ & $5.15 \mathrm{~b}( \pm 0.35)$ \\
\hline Peonidin-3-Glc-Ac ${ }^{\mathrm{d}}$ & $4.07 \mathrm{~b}( \pm 0.14)$ & $6.04 \mathrm{a}( \pm 0.17)$ \\
\hline Malvidin-3-Glc-Ac ${ }^{\mathrm{d}}$ & $49.47 \mathrm{~b}( \pm 1.50)$ & $67.61 \mathrm{a}( \pm 1.47)$ \\
\hline Malvidin-3-Glc-Coum ${ }^{\mathrm{d}}$ & 20.78 a $( \pm 0.86)$ & 21.48 a $( \pm 0.79)$ \\
\hline Total monomeric anthocyanins $\mathrm{e}$ & $355.12 \mathrm{~b}( \pm 6.74)$ & $379.46 \mathrm{a}( \pm 5.11)$ \\
\hline Coloured polymers ${ }^{\mathrm{f}}$ & $8.21 \mathrm{~b}( \pm 0.47)$ & 13.96 a $( \pm 0.43)$ \\
\hline \multicolumn{3}{|l|}{ Flavonols } \\
\hline Unknown flavonol ${ }^{\mathrm{g}}$ & $18.96 \mathrm{~b}( \pm 0.89)$ & $24.64 \mathrm{a}( \pm 0.99)$ \\
\hline Quercetin-3-Gal & data not shown ${ }^{\mathrm{h}}$ & data not shown ${ }^{\mathrm{h}}$ \\
\hline Quercetin-3-Glc & 13.65 a $( \pm 0.49)$ & 14.70 a $( \pm 0.75)$ \\
\hline Quercetin-3-Rham & $8.31 \mathrm{~b}( \pm 0.27)$ & $9.25 \mathrm{a}( \pm 0.29)$ \\
\hline Myricetin & $3.25( \pm 0.18)$ & data not shown ${ }^{\mathrm{h}}$ \\
\hline Quercetin & $4.38 \mathrm{a}( \pm 0.30)$ & $3.37 \mathrm{~b}( \pm 0.14)$ \\
\hline Kaempferol & data not shown ${ }^{\mathrm{h}}$ & $0.67( \pm 0.05)$ \\
\hline Isorhamnetin & data not shown ${ }^{\mathrm{h}}$ & data not shown ${ }^{\mathrm{h}}$ \\
\hline Total flavonols ${ }^{\mathrm{f}}$ & $50.54 \mathrm{a}( \pm 1.91)$ & 53.78 a $( \pm 1.99)$ \\
\hline \multicolumn{3}{|l|}{ Phenolic acids } \\
\hline Gallic acid & $12.75 \mathrm{a}( \pm 0.66)$ & $11.27 \mathrm{a}( \pm 0.63)$ \\
\hline Caftaric acid & 180.78 a $( \pm 4.49)$ & $175.92 \mathrm{a}( \pm 3.22)$ \\
\hline Caffeic acid & $5.60 \mathrm{a}( \pm 0.21)$ & $0.84 \mathrm{~b}( \pm 0.08)$ \\
\hline Coutaric acid ${ }^{\mathrm{i}}$ & $18.45 \mathrm{a}( \pm 0.52)$ & $16.08 \mathrm{~b}( \pm 0.29)$ \\
\hline$p$-Coumaric acid & $2.10 \mathrm{a}( \pm 0.14)$ & $1.40 \mathrm{~b}( \pm 0.10)$ \\
\hline Total phenolic acids ${ }^{\mathrm{f}}$ & 219.69 a $( \pm 4.92)$ & $205.51 \mathrm{~b}( \pm 3.51)$ \\
\hline \multicolumn{3}{|l|}{ Flavan-3-ols } \\
\hline$(+)$-Catechin & $22.63 \mathrm{a}( \pm 0.74)$ & $8.95 \mathrm{~b}( \pm 0.26)$ \\
\hline Procyanidin B1 & $32.04 \mathrm{a}( \pm 1.13)$ & $13.01 \mathrm{~b}( \pm 0.26)$ \\
\hline Non-coloured polymers ${ }^{\mathrm{j}}$ & 119.77 a $( \pm 5.30)$ & $125.17 \mathrm{a}( \pm 6.03)$ \\
\hline Total monomers ${ }^{\mathrm{k}}$ & $680.01 \mathrm{a}( \pm 10.02)$ & $660.71 \mathrm{a}( \pm 6.13)$ \\
\hline
\end{tabular}

${ }^{a} \mathrm{mg} / \mathrm{L}$ unless otherwise noted and means taken over all climatic regions and vine structure treatments for a specific vintage; ${ }^{b}$ different letters in a row denote significant differences $(\mathrm{P}<0.05) ;{ }^{c}$ standard error of mean; ${ }^{\mathrm{d}} \mathrm{mg}$ corresponding anthocyanin-3-Glc equivalents/L; ${ }^{\mathrm{e}} \mathrm{mg}$ malvidin-3-Glc equivalents/L; ${ }^{\mathrm{f}}$ sum of phenolic group content; ${ }^{\mathrm{g}} \mathrm{mg}$ rutin equivalents/L; ${ }^{\mathrm{h}}$ data not shown due to large number of wines without detectable amounts of compound; ${ }^{i} \mathrm{mg} p$-coumaric acid equivalents/L; ${ }^{\mathrm{j}} \mathrm{mg}(+)$-catechin equivalents/L; ${ }^{\mathrm{k}}$ sum of all quantified monomeric phenolic compounds; Gal = galactoside; Glc-Coum = $p$-coumaroylglucoside; Rham $=$ rhamnoside

the correlation for the pooled flavan-3-ol content (DAC) of all three vintages with the $\mathrm{TAC}_{\mathrm{M}}$ was better than for the total phenol content. A very weak correlation $(\mathrm{P}<0.05)$ was observed for the total monomer content (HPLC) with the $\mathrm{TAC}_{\mathrm{M}}$ when data of the 2003 vintage were considered, where no correlation $(\mathrm{P} \geq 0.05)$ was obtained for the 2002 data, although when data of the 2002 and 2003 vintages were pooled, a weak, but significant $(\mathrm{P}<$ $0.001)$ correlation was observed. The $\mathrm{TAC}_{\mathrm{M}}$ had a significant

\section{TABLE 3}

Correlations between phenolic group content and total antioxidant capacity of the 2001, 2002 and 2003 Pinotage wines.

\begin{tabular}{|c|c|c|c|c|}
\hline Phenolic group & $\begin{array}{l}\text { All vintages } \\
\text { (pooled) }\end{array}$ & 2001 & 2002 & 2003 \\
\hline \multicolumn{5}{|l|}{ Spectrophotometric assay } \\
\hline Total phenols ${ }^{\mathrm{a}}$ & $0.361^{\mathrm{b} * *}$ & $0.958 * *$ & $0.885 * *$ & $0.910 * *$ \\
\hline Total anthocyanins $(\mathrm{pH} \text { shift })^{\mathrm{c}}$ & $0.131 \mathrm{~ns}$ & $0.633 * *$ & $0.285 *$ & $0.633 * *$ \\
\hline Total flavan-3-ols (DAC) ${ }^{\mathrm{d}}$ & $0.650 * *$ & $0.926 * *$ & $0.819 * *$ & $0.892 * *$ \\
\hline \multicolumn{5}{|l|}{ HPLC } \\
\hline Total monomers $^{\mathrm{e}}$ & $0.271 * *$ & na & $0.242 \mathrm{~ns}$ & $0.236 *$ \\
\hline Total anthocyanins ${ }^{\mathrm{f}}$ & $-0.315 * *$ & na & $-0.240 \mathrm{~ns}$ & $-0.262 *$ \\
\hline Total flavonols ${ }^{\mathrm{f}}$ & $0.325 * *$ & na & $0.430 * *$ & $0.363 * *$ \\
\hline Total phenolic acids ${ }^{\mathrm{f}}$ & $0.497 * *$ & na & $0.429 * *$ & $0.506 * *$ \\
\hline
\end{tabular}

${ }^{a} \mathrm{mg}$ gallic acid equivalents/L; ${ }^{\mathrm{b}}$ correlation coefficient for correlation between phenolic group and the total antioxidant capacity; ${ }^{\mathrm{c}} \mathrm{mg}$ malvidin-3-glucoside equivalents/L; ${ }^{\mathrm{d}} \mathrm{mg}(+)$-catechin equivalents/L; ${ }^{\mathrm{e}}$ sum of all quantified monomeric phenolic compounds; ${ }^{\mathrm{f}}$ sum of phenolic group content; na = not available.

moderate positive correlation $(\mathrm{P}<0.001)$ with the total anthocyanin content (pH shift) of the 2001 and 2003 vintages only, while the 2002 vintage showed a weak, but significant positive correlation $(\mathrm{P}<0.05)$. On the other hand, the monomeric anthocyanin content (HPLC) showed weak negative correlations $(\mathrm{P}<0.05)$ for the pooled data of the 2002 and 2003 vintages, as well as for the 2003 data separately. The total phenolic acid and total flavonol contents (HPLC) correlated weakly, but significantly $(\mathrm{P}<0.001)$, with the $\mathrm{TAC}_{\mathrm{M}}$ when data for the 2002 and 2003 vintages were considered separately or pooled.

The objective colour parameters, $C^{*}, L^{*}$ and $a^{*}$, of the wines were significantly affected by vintage, but no significant differences were observed for $h^{*}$ and $b^{*}$ (Table 1). The 2002 wines had higher $C^{*}$ values, and the 2001 wines lower $L^{*}$ and $a^{*}$ values than the wines from other years. A plot of $L^{*}$ values against $C^{*}$ values revealed an interesting phenomenon (Fig. 3). As $L^{*}$ decreased, $C^{*}$ increased up to a point, where after an inversion occurs with a further decrease in $L^{*}$ corresponding to a decrease in $C^{*}$. This inversion also occurs for both $a^{*}$ and $b^{*}$.

\section{Climatic region $\mathbf{x}$ vine structure treatment interaction}

Only a small number of interactions between climatic region and vine structure treatment was observed for the wines (Table 4).

During 2002, the climatic region affected the malvidin-3-Glc content of wines only for the trellised vine treatments, with region III wines having a higher content than region II wines (Table 4). Significant differences between wine produced from bush and trellised vines were only observed for region III, with the trellised vine treatments resulting in a higher malvidin-3-Glc content compared to the bush vine treatments. A similar trend, although not significant, was observed for the malvidin-3-Glc content of region II and IV wines. The monomeric anthocyanin content (HPLC) during 2002 followed the same trend as the malvidin-3Glc content.

Different results were obtained for the anthocyanin content of the 2003 wines compared to that observed for the 2002 wines (Table 4). The malvidin-3-Glc-Ac content of wines produced 


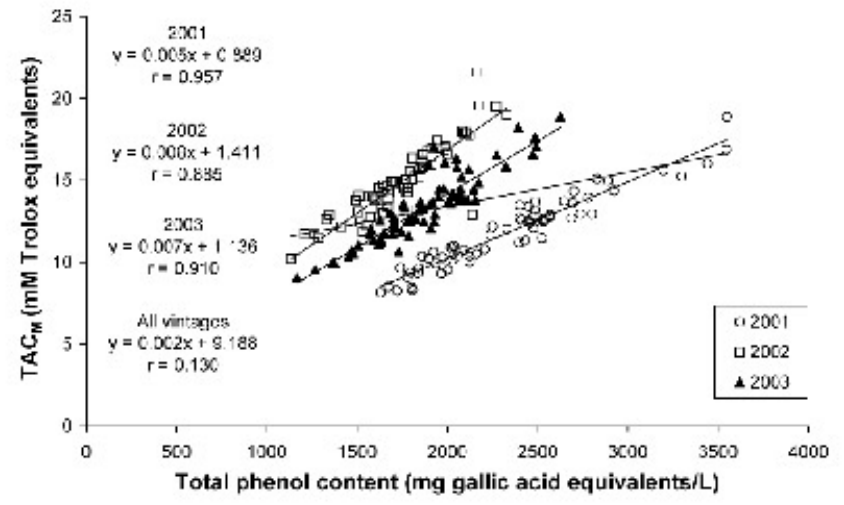

FIGURE 2

Correlation of total phenol content with measured total antioxidant capacity $\left(\mathrm{TAC}_{\mathrm{M}}\right)$ for Pinotage wines.

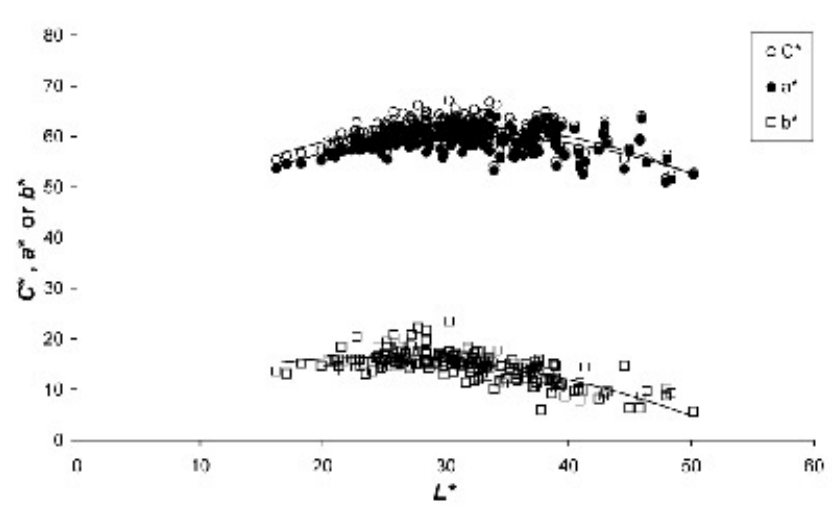

FIGURE 3

Cartesian plot of $L^{*}$ values against $C^{*}$ (chroma), $a^{*}$ (red/green) and $b^{*}$ (yellow/ blue) values for all Pinotage wines.

TABLE 4

Interaction of climatic region and vine structure system with regard to phenolic composition ${ }^{\mathrm{a}}$ of the 2002 and 2003 Pinotage wines.

\begin{tabular}{|c|c|c|c|c|c|c|c|}
\hline \multirow[b]{2}{*}{ Climatic region } & \multirow[b]{2}{*}{ Vine structure treatment } & \multicolumn{3}{|c|}{2002} & \multicolumn{3}{|c|}{2003} \\
\hline & & Mv-3-Glc & $\begin{array}{c}\text { Monomeric } \\
\text { anthocyanins }^{b}\end{array}$ & $\begin{array}{c}p \text {-Coumaric } \\
\text { acid }\end{array}$ & Mv-3-Glc-Ac & Mv-3-Glc-Coum & $\begin{array}{c}p \text {-Coumaric } \\
\text { acid }\end{array}$ \\
\hline \multirow[t]{2}{*}{ Region II } & Bush vines & $194.20 c^{c}( \pm 7.03)^{d}$ & $334.81 \mathrm{c}( \pm 10.15)$ & $1.73 b( \pm 0.25)$ & $57.97 \mathrm{~d}( \pm 1.88)$ & $15.65 \mathrm{~d}( \pm 0.75)$ & $1.00 \mathrm{c}( \pm 0.19)$ \\
\hline & Trellised vines & 202.88 bc $( \pm 11.47)$ & $351.81 \mathrm{bc}( \pm 17.56)$ & $1.72 b( \pm 0.38)$ & $60.77 \mathrm{~cd}( \pm 1.93)$ & $20.59 \mathrm{bc}( \pm 0.80)$ & $1.43 \mathrm{abc}( \pm 0.29)$ \\
\hline \multirow[t]{2}{*}{ Region III } & Bush vines & 188.17 c $( \pm 10.54)$ & $311.93 \mathrm{c}( \pm 16.48)$ & $1.98 \mathrm{~b}( \pm 0.21)$ & $59.90 \mathrm{~cd}( \pm 2.18)$ & $18.21 \mathrm{~cd}( \pm 1.42)$ & $1.65 \mathrm{ab}( \pm 0.28)$ \\
\hline & Trellised vines & 244.31 a $( \pm 13.18)$ & $404.40 \mathrm{a}( \pm 21.27)$ & $2.07 \mathrm{~b}( \pm 0.29)$ & $66.11 \mathrm{bc}( \pm 2.06)$ & $23.66 \mathrm{~b}( \pm 1.59)$ & $1.34 \mathrm{abc}( \pm 0.18)$ \\
\hline \multirow[t]{2}{*}{ Region IV } & Bush vines & 204.82 bc $( \pm 5.73)$ & 341.46 bc $( \pm 9.07)$ & $3.24 \mathrm{a}( \pm 0.38)$ & $71.37 \mathrm{~b}( \pm 2.20)$ & $19.17 \mathrm{~cd}( \pm 1.18)$ & $1.85 \mathrm{a}( \pm 0.29)$ \\
\hline & Trellised vines & $227.34 \mathrm{ab}( \pm 5.46)$ & $380.84 \mathrm{ab}( \pm 8.35)$ & $1.52 \mathrm{~b}( \pm 0.20)$ & $86.61 \mathrm{a}( \pm 2.81)$ & $31.24 \mathrm{a}( \pm 1.30)$ & $1.18 \mathrm{bc}( \pm 0.16)$ \\
\hline
\end{tabular}

${ }^{\mathrm{a}} \mathrm{mg} / \mathrm{L}$ unless otherwise noted; ${ }^{\mathrm{b}}$ sum of phenolic group content; ${ }^{\mathrm{c}}$ different letters in a column denote significant differences $(\mathrm{P}<0.05) ;{ }^{\mathrm{d}}$ standard error of mean; Glc $=$ glucoside; Glc-Ac = acetylglucoside; Glc-Coum = p-coumaroylglucoside; $\mathrm{Mv}=$ malvidin.

from bush vines was lower than that of trellised vines only in region IV. The trend for climatic region, however, was similar for both bush and trellised vines, with region IV wines having a significantly higher content than region II wines. The malvidin-3Glc-Coum content of the wines produced from bush vines was lower than that from trellised vines for all the climatic regions. Significant differences between climatic regions were obtained for trellised vines, with region IV resulting in wines with a higher content than regions II and III.

For both 2002 and 2003, bush vines in region IV gave wines with a significantly higher $p$-coumaric acid content compared to trellised vines (Table 4). Furthermore, the $p$-coumaric acid content of wines from region IV bush vines in 2002 was substantially higher than that of all the other vintages, climatic region and vine structure treatment combinations. The overall lowest $p$-coumaric acid content was observed for wines made from region II bush vines in 2003. In the case of trellised vines, the climatic region did not affect the $p$-coumaric acid content, irrespective of vintage.

No interactions between climatic region and vine structure treatment were observed for any of the antioxidant capacity or objective colour parameters of the wines.

\section{Climatic region: Effect on grape sugar content and phenolic composition}

The grape sugar content did not differ significantly between climatic regions for any of the vintages (Table 5).

In most cases, the climatic region where grapevines were cultivated had a significant impact on the phenolic composition of the wines as measured by spectrophotometric assays (Table 5). This was confirmed by HPLC analysis of individual phenolic compounds (Tables 6 to 8 ).

The total phenol content of the 2001 wines was lower for wines from region IV (warmest) compared to the other regions, while for the 2002 vintage the total phenol content of the wines from the warmest region was significantly lower than that of region II (coolest) (Table 5). For the 2003 vintage, however, the total phenol content of region II and III wines did not differ significantly, but region II wines had a higher total phenol content than region IV wines.

The monomeric, polymeric and total anthocyanin contents $(\mathrm{pH}$ shift) of the wines were lower for the warmest climatic region during 2001 compared to the other regions (Table 5). However, these parameters, as well as the monomeric anthocyanin content 
TABLE 5

Sugar content of grapes and phenolic composition ${ }^{a}$ (measured spectrophotometrically) of the 2001, 2002 and 2003 Pinotage wines.

\begin{tabular}{|c|c|c|c|c|c|c|}
\hline & $\begin{array}{c}\text { Sugar } \\
\text { content }^{b}\end{array}$ & $\begin{array}{c}\text { Total } \\
\text { phenols }^{c}\end{array}$ & $\begin{array}{c}\text { Monomeric } \\
\text { anthocyanins }{ }^{d}\end{array}$ & $\begin{array}{c}\text { Polymeric } \\
\text { anthocyanins }\end{array}$ & $\begin{array}{c}\text { Total } \\
\text { anthocyanins }^{d}\end{array}$ & $\begin{array}{c}\text { Total } \\
\text { flavan-3-ols }\end{array}$ \\
\hline \multicolumn{7}{|c|}{ 2001: Climatic region ${ }^{\mathrm{f}}$} \\
\hline Region II & $25.5 \mathrm{a}^{\mathrm{g}}( \pm 0.2)^{\mathrm{h}}$ & $2618.0 \mathrm{a}( \pm 134.7)$ & 540.4 a $( \pm 21.9)$ & 150.7 a $( \pm 7.2)$ & $691.1 \mathrm{a}( \pm 27.4)$ & $173.8 \mathrm{a}( \pm 12.9)$ \\
\hline Region III & 24.8 a $( \pm 0.2)$ & $2578.5 \mathrm{a}( \pm 93.27)$ & 508.0 a $( \pm 15.1)$ & $138.1 \mathrm{a}( \pm 5.0)$ & $646.1 \mathrm{a}( \pm 19.0)$ & $178.3 \mathrm{a}( \pm 8.9)$ \\
\hline Region IV & $25.0 \mathrm{a}( \pm 0.2)$ & 2032.6 b $( \pm 84.0)$ & $462.9 \mathrm{~b}( \pm 13.6)$ & $115.4 \mathrm{~b}( \pm 4.5)$ & $578.4 \mathrm{~b}( \pm 17.1)$ & $122.8 \mathrm{~b}( \pm 8.1)$ \\
\hline \multicolumn{7}{|c|}{ 2002: Climatic region ${ }^{f}$} \\
\hline Region II & $24.5 \mathrm{a}( \pm 0.2)$ & 1954.6 a $( \pm 70.0)$ & $452.3 \mathrm{a}( \pm 17.8)$ & 54.9 a $( \pm 3.6)$ & $507.1 \mathrm{a}( \pm 20.2)$ & 172.7 a $( \pm 9.0)$ \\
\hline Region III & 24.5 a $( \pm 0.2)$ & $1771.4 \mathrm{ab}( \pm 65.4)$ & 439.3 a $( \pm 16.6)$ & 53.4 a $( \pm 3.4)$ & 492.7 a $( \pm 18.9)$ & $151.3 \mathrm{a}( \pm 8.4)$ \\
\hline Region IV & 25.3 a $( \pm 0.2)$ & $1586.0 \mathrm{~b}( \pm 62.6)$ & 441.9 a $( \pm 15.9)$ & $54.2 \mathrm{a}( \pm 3.2)$ & $496.1 \mathrm{a}( \pm 18.0)$ & $119.9 \mathrm{~b}( \pm 8.0)$ \\
\hline \multicolumn{7}{|c|}{ 2003: Climatic region ${ }^{f}$} \\
\hline Region II & 25.1 a $( \pm 0.2)$ & $1854.9 \mathrm{ab}( \pm 66.3)$ & $465.8 \mathrm{a}( \pm 14.2)$ & $66.1 \mathrm{ab}( \pm 3.8)$ & $532.0 \mathrm{a}( \pm 17.5)$ & $180.6 \mathrm{ab}( \pm 7.5)$ \\
\hline Region III & 24.6 a $( \pm 0.2)$ & 1987.4 a $( \pm 77.1)$ & 471.7 a $( \pm 16.5)$ & $70.2 \mathrm{a}( \pm 4.4)$ & $541.9 \mathrm{a}( \pm 20.3)$ & 197.9 a $( \pm 8.8)$ \\
\hline Region IV & $25.2 \mathrm{a}( \pm 0.2)$ & $1777.7 \mathrm{~b}( \pm 63.1)$ & 449.3 a $( \pm 13.5)$ & $58.1 \mathrm{~b}( \pm 3.6)$ & $507.4 \mathrm{a}( \pm 16.6)$ & $168.5 \mathrm{~b}( \pm 7.2)$ \\
\hline \multicolumn{7}{|c|}{ 2001: Vine structure treatment $\mathrm{t}^{\mathrm{i}}$} \\
\hline Bush vines & 24.9 a $( \pm 0.2)$ & $2449.1 \mathrm{a}( \pm 112.1)$ & 503.5 a $( \pm 15.6)$ & 136.9 a $( \pm 5.9)$ & $640.4 \mathrm{a}( \pm 20.6)$ & $165.1 \mathrm{a}( \pm 10.7)$ \\
\hline Trellised vines & $25.1 \mathrm{a}( \pm 0.2)$ & $2370.2 \mathrm{a}( \pm 113.9)$ & $504.0 \mathrm{a}( \pm 15.9)$ & 132.6 a $( \pm 6.0)$ & $636.6 \mathrm{a}( \pm 21.0)$ & $151.5 \mathrm{a}( \pm 10.8)$ \\
\hline \multicolumn{7}{|c|}{ 2002: Vine structure treatment ${ }^{\mathrm{i}}$} \\
\hline Bush vines & $24.7 \mathrm{a}( \pm 0.1)$ & 1812.0 a $( \pm 62.4)$ & $441.5 \mathrm{a}( \pm 13.3)$ & $58.2 \mathrm{a}( \pm 2.5)$ & $499.7 \mathrm{a}( \pm 15.1)$ & $155.3 \mathrm{a}( \pm 8.2)$ \\
\hline Trellised vines & $25.0 \mathrm{a}( \pm 0.3)$ & 1729.3 a $( \pm 59.2)$ & 447.5 a $( \pm 12.7)$ & $50.1 \mathrm{~b}( \pm 2.3)$ & $497.7 \mathrm{a}( \pm 14.3)$ & 140.6 a $( \pm 7.7)$ \\
\hline \multicolumn{7}{|c|}{ 2003: Vine structure treatment $\mathrm{t}^{\mathrm{i}}$} \\
\hline Bush vines & $25.1 \mathrm{a}( \pm 0.2)$ & 1963.6 a $( \pm 56.2)$ & $461.0 \mathrm{a}( \pm 12.1)$ & 66.9 a $( \pm 3.4)$ & $527.9 \mathrm{a}( \pm 15.2)$ & 194.8 a $( \pm 6.4)$ \\
\hline Trellised vines & 24.9 a $( \pm 0.2)$ & $1783.0 \mathrm{~b}( \pm 56.2)$ & $463.5 \mathrm{a}( \pm 12.1)$ & 62.7 a $( \pm 3.4)$ & $526.3 \mathrm{a}( \pm 15.2)$ & $169.9 \mathrm{~b}( \pm 6.4)$ \\
\hline
\end{tabular}

${ }^{\mathrm{a}}$ all phenolic composition means were adjusted for grape sugar content using covariate analysis; ${ }^{\mathrm{b}}{ }^{\circ} \mathrm{B} ;{ }^{\mathrm{c}}$ mg gallic acid equivalents/L; ${ }^{\mathrm{d}} \mathrm{mg}$ malvidin-3-glucoside equivalents/L; ${ }^{\mathrm{e}} \mathrm{mg}(+)$-catechin equivalents $/ \mathrm{L} ;{ }^{\mathrm{f}}$ means taken over all vine structure treatments for a specific vintage and climatic region as described in Materials and Methods; $\mathrm{g}$ different letters in a group in a column denote significant differences $(\mathrm{P}<0.05) ;{ }^{\mathrm{h}}$ standard error of mean; ${ }^{\mathrm{i}}$ means taken over all climatic regions and cordon heights for a specific vintage.

(HPLC) of the wines, did not differ significantly between wines of different climatic regions for the 2002 vintage (Tables 5 \& 6). The polymeric anthocyanin content ( $\mathrm{pH}$ shift) of the 2003 wines was significantly lower for the wines from region IV compared to those of region III, while no significant differences between wines from different climatic regions were observed for the monomeric and total anthocyanin content ( $\mathrm{pH}$ shift), as well as the monomeric anthocyanin content (HPLC) for the 2003 vintage. The coloured polymer content (HPLC) was not affected by climatic region for either of the 2002 and 2003 vintages. During both 2002 and 2003, a decrease in some individual anthocyanin contents of the wines, namely delphinidin-3-Glc, petunidin-3-Glc and peonidin-3-Glc, was observed from the coolest to the warmest climatic region, while the opposite trend was observed for other anthocyanins, namely vitisin A in 2002, and malvidin3-Glc-Ac and malvidin-3-Glc-Coum in 2003 (Table 6). The malvidin-3-Glc, delphinidin-3-Glc-Ac, petunidin-3-Glc-Ac and peonidin-3-Glc-Ac contents of the wines, on the other hand, were not affected by climatic region of either of the vintages.

The total flavonols, quercetin and the unknown flavonol were significantly more abundant in region II wines, compared to region III and IV wines of the 2002 vintage (Table 7). The climatic regions had no significant effect on the flavonol content of wines from different climatic regions during 2003. Quercetin-3Glc was significantly less abundant in region III wines, compared to region II and IV wines of the 2002 vintage, while quercetin-3Rham content of region III wines was lower than that of region II only.

The climatic regions did not affect the phenolic acid content of the 2003 wines, but total phenolic acid content and some individual phenolic acids of the 2002 wines were affected (Table 8). Region II gave wines with a higher total phenolic acid content than the other regions. These wines also contained significantly higher caftaric and coutaric acid contents. Wines produced from region III grapes had a higher gallic acid content than those from region IV grapes.

Trends for the flavan-3-ol content of wines from different climatic regions also differed for the three vintages investigated (Tables 5 \& 8). In 2001 and 2002, the warmest region produced wine containing a lower total flavan-3-ol content (DAC) than wines from the other regions. In the case of the 2003 wines, the total flavan-3-ol content (DAC) did not differ significantly between region II and III wines, but region III wines had a significantly higher total flavan-3-ol content (DAC) than region IV wines. The non-coloured polymer content of the 2002 wines was not affected by climatic region, while the 2003 wines from region II had significantly less non-coloured polymers than the wines from region III. Climatic region only had an effect on the (+)-catechin and procyanidin B1 contents in 2002. (+)-Catechin and procyanidin B1 concentrations were higher for wines from the 
TABLE 6

Anthocyanin content ${ }^{\mathrm{a}}$ of the 2002 and 2003 Pinotage wines.

\begin{tabular}{|c|c|c|c|c|c|c|c|c|c|c|c|c|}
\hline & \multicolumn{11}{|c|}{ Monomeric anthocyanins } & \multirow{2}{*}{$\begin{array}{c}\text { Coloured } \\
\text { polymers }^{\mathrm{d}}\end{array}$} \\
\hline & $\begin{array}{c}\text { Dp-3- } \\
\text { Glc }\end{array}$ & $\begin{array}{c}\text { Pt-3- } \\
\text { Glc }\end{array}$ & $\begin{array}{c}\text { Pn-3- } \\
\text { Glc }\end{array}$ & $\begin{array}{c}\text { Mv-3- } \\
\text { Glc }\end{array}$ & $\begin{array}{c}\text { Dp-3- } \\
\text { Glc-Ac }^{b}\end{array}$ & $\begin{array}{c}\text { Vitisin } \\
\mathbf{A}^{\mathbf{b}}\end{array}$ & $\begin{array}{c}\text { Pt-3- } \\
\text { Glc-Ac }\end{array}$ & $\begin{array}{c}\text { Pn-3- } \\
\text { Glc-Ac }\end{array}$ & $\begin{array}{c}\text { Mv-3-Glc- } \\
\text { Ac }^{\mathrm{b}}\end{array}$ & $\begin{array}{l}\text { Mv-3-Glc- } \\
\text { Coumb }^{b}\end{array}$ & Total $^{c}$ & \\
\hline \multicolumn{13}{|c|}{ 2002: Climatic region ${ }^{\mathrm{e}}$} \\
\hline Region II & $\begin{array}{l}20.98 \mathrm{a}^{\mathrm{f}} \\
( \pm 1.00)^{\mathrm{g}}\end{array}$ & $\begin{array}{l}26.99 \mathrm{a} \\
( \pm 0.83)\end{array}$ & $\begin{array}{l}12.12 \mathrm{a} \\
( \pm 0.85)\end{array}$ & $\begin{array}{l}200.67 \mathrm{a} \\
( \pm 10.90)\end{array}$ & $\begin{array}{c}6.55 \mathrm{a} \\
( \pm 0.44)\end{array}$ & $\begin{array}{c}4.71 \mathrm{~b} \\
( \pm 0.82)\end{array}$ & $\begin{array}{c}6.45 \mathrm{a} \\
( \pm 0.43)\end{array}$ & $\begin{array}{c}4.28 \mathrm{a} \\
( \pm 0.28)\end{array}$ & $\begin{array}{l}44.17 \mathrm{a} \\
( \pm 3.56)\end{array}$ & $\begin{array}{c}19.22 \mathrm{a} \\
( \pm 1.53)\end{array}$ & $\begin{array}{l}345.47 \mathrm{a} \\
( \pm 17.39)\end{array}$ & $\begin{array}{c}6.96 \mathrm{a} \\
( \pm 0.96)\end{array}$ \\
\hline Region III & $\begin{array}{l}16.68 \mathrm{~b} \\
( \pm 0.74)\end{array}$ & $\begin{array}{l}24.73 \mathrm{ab} \\
( \pm 1.01)\end{array}$ & $\begin{array}{c}9.38 \mathrm{~b} \\
( \pm 0.76)\end{array}$ & $\begin{array}{c}217.55 \mathrm{a} \\
( \pm 9.79)\end{array}$ & $\begin{array}{c}6.03 \mathrm{a} \\
( \pm 0.40)\end{array}$ & $\begin{array}{l}5.74 \mathrm{ab} \\
( \pm 0.74)\end{array}$ & $\begin{array}{c}6.11 \mathrm{a} \\
( \pm 0.39)\end{array}$ & $\begin{array}{c}4.30 \mathrm{a} \\
( \pm 0.29)\end{array}$ & $\begin{array}{l}48.67 \mathrm{a} \\
( \pm 3.20)\end{array}$ & $\begin{array}{l}20.96 \mathrm{a} \\
( \pm 1.65)\end{array}$ & $\begin{array}{l}359.93 \mathrm{a} \\
( \pm 15.63)\end{array}$ & $\begin{array}{c}7.67 \mathrm{a} \\
( \pm 0.87)\end{array}$ \\
\hline Region IV & $\begin{array}{l}14.11 \mathrm{c} \\
( \pm 0.82)\end{array}$ & $\begin{array}{l}22.14 b \\
( \pm 0.36)\end{array}$ & $\begin{array}{c}8.30 \mathrm{~b} \\
( \pm 0.75)\end{array}$ & $\begin{array}{l}214.36 \mathrm{a} \\
( \pm 9.66)\end{array}$ & $\begin{array}{c}6.02 \mathrm{a} \\
( \pm 0.39)\end{array}$ & $\begin{array}{c}7.69 \mathrm{a} \\
( \pm 0.73)\end{array}$ & $\begin{array}{c}6.18 \mathrm{a} \\
( \pm 0.38)\end{array}$ & $\begin{array}{c}3.74 \mathrm{a} \\
( \pm 0.18)\end{array}$ & $\begin{array}{l}53.79 \mathrm{a} \\
( \pm 3.16)\end{array}$ & $\begin{array}{l}21.71 \mathrm{a} \\
( \pm 1.32)\end{array}$ & $\begin{array}{l}358.78 \mathrm{a} \\
( \pm 15.41)\end{array}$ & $\begin{array}{c}9.36 \mathrm{a} \\
( \pm 0.85)\end{array}$ \\
\hline \multicolumn{13}{|c|}{ 2003: Climatic region ${ }^{\mathrm{e}}$} \\
\hline Region II & $\begin{array}{l}15.54 \mathrm{a} \\
( \pm 1.04)\end{array}$ & $\begin{array}{l}23.35 \mathrm{a} \\
( \pm 1.16)\end{array}$ & $\begin{array}{c}6.89 \mathrm{a} \\
( \pm 0.66)\end{array}$ & $\begin{array}{l}224.71 \mathrm{a} \\
( \pm 4.88)\end{array}$ & $\begin{array}{c}4.91 \mathrm{a} \\
( \pm 0.40)\end{array}$ & $\begin{array}{c}4.41 \mathrm{a} \\
( \pm 0.87)\end{array}$ & $\begin{array}{c}6.14 \mathrm{a} \\
( \pm 0.92)\end{array}$ & $\begin{array}{c}6.50 \mathrm{a} \\
( \pm 0.40)\end{array}$ & $\begin{array}{l}59.26 \mathrm{~b} \\
( \pm 1.35)\end{array}$ & $\begin{array}{l}18.19 \mathrm{~b} \\
( \pm 1.67)\end{array}$ & $\begin{array}{l}370.49 \mathrm{a} \\
( \pm 7.15)\end{array}$ & $\begin{array}{l}13.17 \mathrm{a} \\
( \pm 0.79)\end{array}$ \\
\hline Region III & $\begin{array}{l}14.48 \mathrm{a} \\
( \pm 1.20)\end{array}$ & $\begin{array}{l}21.91 \mathrm{ab} \\
( \pm 1.35)\end{array}$ & $\begin{array}{l}5.89 \mathrm{ab} \\
( \pm 0.77)\end{array}$ & $\begin{array}{l}229.15 \mathrm{a} \\
( \pm 5.60)\end{array}$ & $\begin{array}{c}4.73 \mathrm{a} \\
( \pm 0.47)\end{array}$ & $\begin{array}{c}6.50 \mathrm{a} \\
( \pm 1.01)\end{array}$ & $\begin{array}{c}4.61 \mathrm{a} \\
( \pm 0.34)\end{array}$ & $\begin{array}{c}5.78 \mathrm{a} \\
( \pm 0.46)\end{array}$ & $\begin{array}{l}63.01 \mathrm{~b} \\
( \pm 1.61)\end{array}$ & $\begin{array}{l}20.72 \mathrm{ab} \\
( \pm 1.95)\end{array}$ & $\begin{array}{l}375.79 \mathrm{a} \\
( \pm 9.43)\end{array}$ & $\begin{array}{l}15.08 \mathrm{a} \\
( \pm 0.91)\end{array}$ \\
\hline Region IV & $\begin{array}{l}10.81 \mathrm{~b} \\
( \pm 0.99)\end{array}$ & $\begin{array}{l}18.66 \mathrm{~b} \\
( \pm 1.10)\end{array}$ & $\begin{array}{c}4.24 \mathrm{~b} \\
( \pm 0.63)\end{array}$ & $\begin{array}{l}232.53 \mathrm{a} \\
( \pm 5.64)\end{array}$ & $\begin{array}{c}4.21 \mathrm{a} \\
( \pm 0.38)\end{array}$ & $\begin{array}{c}5.37 \mathrm{a} \\
( \pm 0.83)\end{array}$ & $\begin{array}{c}4.65 \mathrm{a} \\
( \pm 0.30)\end{array}$ & $\begin{array}{c}5.81 \mathrm{a} \\
( \pm 0.38)\end{array}$ & $\begin{array}{l}78.99 \mathrm{a} \\
( \pm 2.28)\end{array}$ & $\begin{array}{l}25.46 \mathrm{a} \\
( \pm 1.60)\end{array}$ & $\begin{array}{l}390.68 \mathrm{a} \\
( \pm 9.55)\end{array}$ & $\begin{array}{l}13.93 \mathrm{a} \\
( \pm 0.75)\end{array}$ \\
\hline \multicolumn{13}{|c|}{ 2002: Vine structure treatment ${ }^{\mathrm{h}}$} \\
\hline Bush vines & $\begin{array}{l}15.73 b \\
( \pm 0.76)\end{array}$ & $\begin{array}{l}22.96 \mathrm{~b} \\
( \pm 0.71)\end{array}$ & $\begin{array}{l}10.32 \mathrm{a} \\
( \pm 0.76)\end{array}$ & $\begin{array}{l}197.01 \mathrm{~b} \\
( \pm 7.20)\end{array}$ & $\begin{array}{c}5.90 \mathrm{a} \\
( \pm 0.33)\end{array}$ & $\begin{array}{c}6.62 \mathrm{a} \\
( \pm 0.65)\end{array}$ & $\begin{array}{c}6.02 \mathrm{a} \\
( \pm 0.32)\end{array}$ & $\begin{array}{c}4.40 \mathrm{a} \\
( \pm 0.19)\end{array}$ & $\begin{array}{l}44.62 \mathrm{~b} \\
( \pm 2.57)\end{array}$ & $\begin{array}{l}16.58 \mathrm{~b} \\
( \pm 0.67)\end{array}$ & $\begin{array}{l}331.08 \mathrm{~b} \\
( \pm 10.93)\end{array}$ & $\begin{array}{c}7.29 \mathrm{a} \\
( \pm 0.70)\end{array}$ \\
\hline Trellised vines & $\begin{array}{l}19.92 \mathrm{a} \\
( \pm 0.91)\end{array}$ & $\begin{array}{l}25.64 \mathrm{a} \\
( \pm 0.92)\end{array}$ & $\begin{array}{c}9.55 \mathrm{a} \\
( \pm 0.73)\end{array}$ & $\begin{array}{c}224.71 \mathrm{a} \\
( \pm 6.96)\end{array}$ & $\begin{array}{c}6.49 \mathrm{a} \\
( \pm 0.32)\end{array}$ & $\begin{array}{c}5.48 \mathrm{a} \\
( \pm 0.63)\end{array}$ & $\begin{array}{c}6.50 \mathrm{a} \\
( \pm 0.31)\end{array}$ & $\begin{array}{c}3.74 \mathrm{~b} \\
( \pm 0.20)\end{array}$ & $\begin{array}{l}53.13 \mathrm{a} \\
( \pm 2.49)\end{array}$ & $\begin{array}{l}24.99 \mathrm{a} \\
( \pm 1.17)\end{array}$ & $\begin{array}{l}378.37 \mathrm{a} \\
( \pm 10.57)\end{array}$ & $\begin{array}{c}8.70 \mathrm{a} \\
( \pm 0.67)\end{array}$ \\
\hline \multicolumn{13}{|c|}{ 2003: Vine structure treatment ${ }^{\mathrm{h}}$} \\
\hline Bush vines & $\begin{array}{l}14.50 \mathrm{a} \\
( \pm 1.01)\end{array}$ & $\begin{array}{l}21.89 \mathrm{a} \\
( \pm 1.10)\end{array}$ & $\begin{array}{c}6.88 \mathrm{a} \\
( \pm 0.56)\end{array}$ & $\begin{array}{c}216.17 \mathrm{~b} \\
( \pm 3.24)\end{array}$ & $\begin{array}{c}4.88 \mathrm{a} \\
( \pm 0.34)\end{array}$ & $\begin{array}{c}5.55 \mathrm{a} \\
( \pm 0.74)\end{array}$ & $\begin{array}{c}5.62 \mathrm{a} \\
( \pm 0.64)\end{array}$ & $\begin{array}{c}6.65 \mathrm{a} \\
( \pm 0.30)\end{array}$ & $\begin{array}{l}63.32 \mathrm{~b} \\
( \pm 1.53)\end{array}$ & $\begin{array}{l}17.89 \mathrm{~b} \\
( \pm 1.28)\end{array}$ & $\begin{array}{c}362.22 \mathrm{~b} \\
( \pm 5.61)\end{array}$ & $\begin{array}{l}12.86 \mathrm{~b} \\
( \pm 0.57)\end{array}$ \\
\hline Trellised vines & $\begin{array}{l}12.72 \mathrm{a} \\
( \pm 1.01)\end{array}$ & $\begin{array}{l}20.72 \mathrm{a} \\
( \pm 1.10)\end{array}$ & $\begin{array}{c}4.47 \mathrm{~b} \\
( \pm 0.56)\end{array}$ & $\begin{array}{l}242.27 \mathrm{a} \\
( \pm 4.45)\end{array}$ & $\begin{array}{c}4.36 \mathrm{a} \\
( \pm 0.34)\end{array}$ & $\begin{array}{c}5.29 \mathrm{a} \\
( \pm 0.74)\end{array}$ & $\begin{array}{c}4.65 \mathrm{a} \\
( \pm 0.25)\end{array}$ & $\begin{array}{c}5.41 \mathrm{~b} \\
( \pm 0.30)\end{array}$ & $\begin{array}{l}72.14 \mathrm{a} \\
( \pm 2.34)\end{array}$ & $\begin{array}{l}25.02 \mathrm{a} \\
( \pm 1.28)\end{array}$ & $\begin{array}{l}397.64 \mathrm{a} \\
( \pm 7.68)\end{array}$ & $\begin{array}{l}15.26 \mathrm{a} \\
( \pm 0.57)\end{array}$ \\
\hline
\end{tabular}

a mg/L unless otherwise noted; most means were adjusted for grape sugar content using covariate analysis except for Dp-3-Glc, Pt-3-Glc, Pn-3-Glc-Ac and Mv-3-GlcCoum contents in 2002 and Mv-3-Glc, Pt-3-Glc-Ac, Mv-3-Glc-Ac and total monomeric anthocyanin contents in 2003; ${ }^{b}$ mg corresponding anthocyanin-3-Glc equivalents/L; ${ }^{\mathrm{c}}$ sum of phenolic group content; ${ }^{\mathrm{d}} \mathrm{mg}$ malvidin-3-Glc equivalents/L; ${ }^{\mathrm{e}}$ means taken over all vine structure treatments for a specific vintage and climatic region as described in Materials and Methods; ${ }^{\mathrm{f}}$ different letters within a group in a column denote significant differences $(\mathrm{P}<0.05) ;{ }^{\mathrm{g}}$ standard error of mean; ${ }^{\mathrm{h}}$ means taken over all climatic regions and cordon heights for a specific vintage; $\mathrm{Dp}=$ delphinidin; Glc = glucoside; Glc-Ac = acetylglucoside; $\mathrm{Glc}-\mathrm{Coum}=p$-coumaroylglucoside; $\mathrm{Pt}=$ petunidin; Pn = peonidin; $\mathrm{Mv}=$ malvidin.

coolest region compared to wines from the warmest region in 2002 .

The total monomer content (HPLC) was affected only in 2002, with wines produced from the coolest region having a higher content (Table 8).

\section{Climatic region: Effect on antioxidant capacity}

The $\mathrm{TAC}_{\mathrm{M}}$ of the wines was affected by the climatic region for only the 2001 and 2002 vintages (Table 9). Regions II and III produced wines with significantly higher $\mathrm{TAC}_{\mathrm{M}}$ values, compared to that of region IV, for both the 2001 and 2002 vintages. No TAC$\mathrm{CAL}_{\mathrm{L}}$ or $\mathrm{TAC}_{\mathrm{R}}$ data are available for the 2001 wines as the phenolic content of these wines was not analysed using HPLC. The TACCAL of the wines from region II was significantly higher than that of regions III and IV during 2002, while no significant difference was observed during 2003. The $\mathrm{TAC}_{\mathrm{R}}$ comprised between 80 and $90 \%$ of the $\mathrm{TAC}_{\mathrm{M}}$ and followed similar trends. The phenolic acid and anthocyanin contents contributed the most to the TAC $\mathrm{CAL}_{\mathrm{CAL}}$ of the 2002 and 2003 wines (Fig. 4). The contributions of phenolic acids and flavonols to the $\mathrm{TAC}_{\mathrm{CAL}}$ were higher for region II wines compared to wines from the other regions during 2002, while the TAC contribution from flavan-3-ols was higher for wines from region II compared to wines from region IV. During 2003, the $\mathrm{TAC}_{\mathrm{CAL}}$ contribution of flavonols of the region II wines was not significantly different from that of the region IV wines, but significantly higher than that of the region III wines. The $\mathrm{TAC}_{\mathrm{CAL}}$ contributions of anthocyanins in 2002, and phenolic acids, flavan3 -ols and anthocyanins in 2003, were not affected by climatic region.

\section{Climatic region: Effect on objective colour parameters}

The objective colour parameters of the wines were only affected by climatic region for the 2001 and 2002 vintages, with wines from the 2001 vintage the most affected (Table 9). Wines from region IV had higher $L^{*}$ and lower $C^{*}$ and $b^{*}$ values than wine from the other regions of the 2001 vintage. The $a^{*}$ values of region III wines were significantly higher than those of region IV wines, while $h^{*}$ values of region II wines were significantly higher than those from the other regions for the 2001 vintage. In the case of the 2002 wines, only $C^{*}, a^{*}$ and $b^{*}$ values were affected by climatic region. The $C^{*}$ and $a^{*}$ values of region II wines were significantly higher than wines from region III and IV, while the $b^{*}$ values of region II wines were significantly higher than region III wines. Wines from the 2003 vintage also showed a slightly 
TABLE 7

Flavonol content ${ }^{\mathrm{a}}$ of the 2002 and 2003 Pinotage wines.

\begin{tabular}{|c|c|c|c|c|c|c|c|}
\hline & $\begin{array}{l}\text { Unknown } \\
\text { compounds }^{b}\end{array}$ & Q-3-Glc & Q-3-Rham & Myricetin & Quercetin & Kaempferol & Total $^{\mathrm{c}}$ \\
\hline \multicolumn{8}{|c|}{ 2002: Climatic region ${ }^{\mathrm{d}}$} \\
\hline Region II & $23.29 \mathrm{a}^{\mathrm{e}}( \pm 1.89)^{\mathrm{f}}$ & $14.82 \mathrm{a}( \pm 1.17)$ & $9.66 \mathrm{a}( \pm 0.69)$ & $2.91 \mathrm{a}( \pm 0.71)$ & $6.44 \mathrm{a}( \pm 0.53)$ & data not shown ${ }^{\mathrm{g}}$ & $60.73 \mathrm{a}( \pm 4.13)$ \\
\hline Region III & $16.09 \mathrm{~b}( \pm 1.00)$ & $11.57 \mathrm{~b}( \pm 0.79)$ & $7.69 \mathrm{~b}( \pm 0.62)$ & $3.31 \mathrm{a}( \pm 0.27)$ & $3.68 \mathrm{~b}( \pm 0.49)$ & data not shown ${ }^{\mathrm{g}}$ & $43.84 \mathrm{~b}( \pm 2.61)$ \\
\hline Region IV & $18.31 \mathrm{~b}( \pm 1.39)$ & $14.53 \mathrm{a}( \pm 0.52)$ & $7.90 \mathrm{ab}( \pm 0.61)$ & $3.44 \mathrm{a}( \pm 0.33)$ & $3.54 \mathrm{~b}( \pm 0.34)$ & data not shown ${ }^{\mathrm{g}}$ & $48.97 \mathrm{~b}( \pm 2.55)$ \\
\hline \multicolumn{8}{|c|}{ 2003: Climatic region ${ }^{\mathrm{d}}$} \\
\hline Region II & 24.95 a $( \pm 1.99)$ & $15.92 \mathrm{a}( \pm 1.58)$ & $9.84 \mathrm{a}( \pm 0.59)$ & data not shown ${ }^{\mathrm{g}}$ & $3.52 \mathrm{a}( \pm 0.29)$ & $0.74 \mathrm{a}( \pm 0.11)$ & $56.27 \mathrm{a}( \pm 4.07)$ \\
\hline Region III & $22.97 \mathrm{a}( \pm 2.32)$ & $12.07 \mathrm{a}( \pm 1.84)$ & $8.33 \mathrm{a}( \pm 0.69)$ & data not shown ${ }^{\mathrm{g}}$ & $3.39 \mathrm{a}( \pm 0.33)$ & $0.62 \mathrm{a}( \pm 0.12)$ & $48.46 \mathrm{a}( \pm 4.74)$ \\
\hline Region IV & $25.50 \mathrm{a}( \pm 1.90)$ & $15.18 \mathrm{a}( \pm 1.50)$ & $9.22 \mathrm{a}( \pm 0.56)$ & data not shown ${ }^{\mathrm{g}}$ & $3.20 \mathrm{a}( \pm 0.27)$ & $0.63 \mathrm{a}( \pm 0.10)$ & $54.61 \mathrm{a}( \pm 3.88)$ \\
\hline \multicolumn{8}{|c|}{ 2002: Vine structure treatment ${ }^{\mathrm{h}}$} \\
\hline Bush vines & $17.73 \mathrm{a}( \pm 1.07)$ & 14.57 a $( \pm 0.59)$ & $8.62 \mathrm{a}( \pm 0.54)$ & $3.26 \mathrm{a}( \pm 0.28)$ & $4.51 \mathrm{a}( \pm 0.45)$ & data not shown ${ }^{\mathrm{g}}$ & $50.95 \mathrm{a}( \pm 2.70)$ \\
\hline Trellised vines & $20.19 \mathrm{a}( \pm 1.41)$ & $12.73 \mathrm{a}( \pm 0.75)$ & $8.22 \mathrm{a}( \pm 0.52)$ & $3.25 \mathrm{a}( \pm 0.22)$ & $4.24 \mathrm{a}( \pm 0.39)$ & data not shown ${ }^{\mathrm{g}}$ & $50.13 \mathrm{a}( \pm 2.75)$ \\
\hline \multicolumn{8}{|c|}{ 2003: Vine structure treatment ${ }^{\mathrm{h}}$} \\
\hline Bush vines & $25.45 \mathrm{a}( \pm 1.43)$ & $16.05 \mathrm{a}( \pm 1.29)$ & $9.90 \mathrm{a}( \pm 0.47)$ & data not shown ${ }^{\mathrm{g}}$ & $3.73 \mathrm{a}( \pm 0.23)$ & $0.75 \mathrm{a}( \pm 0.09)$ & 56.95 a $( \pm 3.30)$ \\
\hline Trellised vines & 23.79 a $( \pm 0.85)$ & $12.73 \mathrm{a}( \pm 1.29)$ & $8.36 \mathrm{~b}( \pm 0.47)$ & data not shown ${ }^{\mathrm{g}}$ & $3.01 \mathrm{~b}( \pm 0.23)$ & $0.57 \mathrm{a}( \pm 0.09)$ & $49.27 \mathrm{a}( \pm 3.29)$ \\
\hline
\end{tabular}

${ }^{a} \mathrm{mg} / \mathrm{L}$ unless otherwise noted; most means were adjusted for grape sugar content using covariate analysis except for unknown flavonol, Q-3-Glc, myricetin, quercetin and total flavonol contents in 2002; ${ }^{b}$ mg rutin equivalents/L; ${ }^{c}$ sum of phenolic group content; ${ }^{\mathrm{d}}$ means taken over all vine structure treatments for a specific vintage or climatic region as described in Materials and Methods; ${ }^{\mathrm{e}}$ different letters within a group in a column denote significant differences $(\mathrm{P}<0.05) ;{ }^{\mathrm{f}}$ standard error of mean; ${ }^{\mathrm{g}}$ data not shown due to large number of wines without detectable amounts of compound; ${ }^{\mathrm{h}}$ means taken over all climatic regions and cordon heights for a specific vintage; Glc = glucoside; $\mathrm{Q}=$ quercetin; Rham = rhamnoside.

\section{TABLE 8}

Phenolic acid, flavan-3-ol and polymer contents of the 2002 and 2003 Pinotage wines.

\begin{tabular}{|c|c|c|c|c|c|c|c|c|c|c|}
\hline & \multicolumn{6}{|c|}{ Phenolic acids } & \multicolumn{3}{|c|}{ Flavan-3-ols } & \multirow{2}{*}{$\begin{array}{c}\text { Total } \\
\text { monomers }\end{array}$} \\
\hline & $\begin{array}{l}\text { Gallic } \\
\text { acid }\end{array}$ & $\begin{array}{l}\text { Caftaric } \\
\text { acid }\end{array}$ & $\begin{array}{c}\text { Caffeic } \\
\text { acid }\end{array}$ & $\begin{array}{l}\text { Coutaric } \\
\text { acid }^{\mathrm{b}}\end{array}$ & $\begin{array}{c}p \text {-Coumaric } \\
\text { acid }\end{array}$ & Total $^{\mathrm{c}}$ & $\begin{array}{c}(+)- \\
\text { Catechin }\end{array}$ & $\begin{array}{c}\text { Procyanidin } \\
\text { B1 }\end{array}$ & $\begin{array}{c}\text { Non-coloured } \\
\text { polymers }^{\mathrm{d}}\end{array}$ & \\
\hline \multicolumn{11}{|c|}{ 2002: Climatic region $\mathrm{f}$} \\
\hline Region II & $\begin{array}{l}13.87 \mathrm{ab}^{\mathrm{g}} \\
( \pm 1.61)^{\mathrm{h}}\end{array}$ & $\begin{array}{l}209.45 \mathrm{a} \\
( \pm 5.72)\end{array}$ & $\begin{array}{c}5.51 \mathrm{a} \\
( \pm 0.27)\end{array}$ & $\begin{array}{l}22.31 \mathrm{a} \\
( \pm 0.73)\end{array}$ & $\begin{array}{c}1.80 \mathrm{a} \\
( \pm 0.37)\end{array}$ & $\begin{array}{l}252.37 \mathrm{a} \\
( \pm 6.52)\end{array}$ & $\begin{array}{l}26.78 \mathrm{a} \\
( \pm 1.58)\end{array}$ & $\begin{array}{l}37.83 \mathrm{a} \\
( \pm 2.39)\end{array}$ & $\begin{array}{l}116.97 \mathrm{a} \\
( \pm 10.21)\end{array}$ & $\begin{array}{l}721.66 \mathrm{a} \\
( \pm 19.62)\end{array}$ \\
\hline Region III & $\begin{array}{r}14.90 \mathrm{a} \\
( \pm 1.45)\end{array}$ & $\begin{array}{l}171.49 \mathrm{~b} \\
( \pm 8.03)\end{array}$ & $\begin{array}{c}5.68 \mathrm{a} \\
( \pm 0.35)\end{array}$ & $\begin{array}{l}17.92 \mathrm{~b} \\
( \pm 0.82)\end{array}$ & $\begin{array}{c}2.11 \mathrm{a} \\
( \pm 0.34)\end{array}$ & $\begin{array}{c}211.59 \mathrm{~b} \\
( \pm 8.01)\end{array}$ & $\begin{array}{l}23.17 \mathrm{ab} \\
( \pm 1.42)\end{array}$ & $\begin{array}{l}32.00 \mathrm{ab} \\
( \pm 2.15)\end{array}$ & $\begin{array}{l}122.29 \mathrm{a} \\
( \pm 10.35)\end{array}$ & $\begin{array}{l}668.87 \mathrm{~b} \\
( \pm 19.42)\end{array}$ \\
\hline Region IV & $\begin{array}{l}10.12 \mathrm{~b} \\
( \pm 1.43)\end{array}$ & $\begin{array}{l}168.72 b \\
( \pm 6.26)\end{array}$ & $\begin{array}{c}5.61 \mathrm{a} \\
( \pm 0.42)\end{array}$ & $\begin{array}{l}16.24 \mathrm{~b} \\
( \pm 0.64)\end{array}$ & $\begin{array}{c}2.21 \mathrm{a} \\
( \pm 0.33)\end{array}$ & $\begin{array}{c}203.94 \mathrm{~b} \\
( \pm 7.07)\end{array}$ & $\begin{array}{l}19.41 \mathrm{~b} \\
( \pm 1.40)\end{array}$ & $\begin{array}{l}28.13 \mathrm{~b} \\
( \pm 2.12)\end{array}$ & $\begin{array}{l}119.66 \mathrm{a} \\
( \pm 7.83)\end{array}$ & $\begin{array}{l}660.61 \mathrm{~b} \\
( \pm 12.26)\end{array}$ \\
\hline \multicolumn{11}{|c|}{ 2003: Climatic region ${ }^{f}$} \\
\hline Region II & $\begin{array}{l}10.64 \mathrm{a} \\
( \pm 0.59)\end{array}$ & $\begin{array}{l}176.40 \mathrm{a} \\
( \pm 5.88)\end{array}$ & $\begin{array}{c}0.99 \mathrm{a} \\
( \pm 0.15)\end{array}$ & $\begin{array}{l}16.61 \mathrm{a} \\
( \pm 0.62)\end{array}$ & $\begin{array}{c}1.20 \mathrm{a} \\
( \pm 0.17)\end{array}$ & $\begin{array}{l}205.84 \mathrm{a} \\
( \pm 6.59)\end{array}$ & $\begin{array}{c}9.28 \mathrm{a} \\
( \pm 0.44)\end{array}$ & $\begin{array}{l}12.33 \mathrm{a} \\
( \pm 0.57)\end{array}$ & $\begin{array}{l}111.44 \mathrm{~b} \\
( \pm 10.59)\end{array}$ & $\begin{array}{l}656.63 \mathrm{a} \\
( \pm 11.80)\end{array}$ \\
\hline Region III & $\begin{array}{r}12.44 \mathrm{a} \\
( \pm 1.26)\end{array}$ & $\begin{array}{l}177.13 \mathrm{a} \\
( \pm 7.12)\end{array}$ & $\begin{array}{c}0.78 \mathrm{a} \\
( \pm 0.13)\end{array}$ & $\begin{array}{l}16.16 \mathrm{a} \\
( \pm 0.58)\end{array}$ & $\begin{array}{c}1.50 \mathrm{a} \\
( \pm 0.17)\end{array}$ & $\begin{array}{l}208.00 \mathrm{a} \\
( \pm 7.65)\end{array}$ & $\begin{array}{c}8.89 \mathrm{a} \\
( \pm 0.48)\end{array}$ & $\begin{array}{l}14.09 \mathrm{a} \\
( \pm 0.66)\end{array}$ & $\begin{array}{l}144.92 \mathrm{a} \\
( \pm 12.31)\end{array}$ & $\begin{array}{l}657.66 \mathrm{a} \\
( \pm 13.72)\end{array}$ \\
\hline Region IV & $\begin{array}{l}10.93 \mathrm{a} \\
( \pm 1.30)\end{array}$ & $\begin{array}{l}174.53 \mathrm{a} \\
( \pm 4.15)\end{array}$ & $\begin{array}{c}0.76 \mathrm{a} \\
( \pm 0.12)\end{array}$ & $\begin{array}{l}15.52 \mathrm{a} \\
( \pm 0.33)\end{array}$ & $\begin{array}{c}1.51 \mathrm{a} \\
( \pm 0.17)\end{array}$ & $\begin{array}{l}203.26 \mathrm{a} \\
( \pm 4.41)\end{array}$ & $\begin{array}{c}8.69 \mathrm{a} \\
( \pm 0.42)\end{array}$ & $\begin{array}{l}12.61 \mathrm{a} \\
( \pm 0.54)\end{array}$ & $\begin{array}{l}122.76 \mathrm{ab} \\
( \pm 10.09)\end{array}$ & $\begin{array}{l}671.66 \mathrm{a} \\
( \pm 11.24)\end{array}$ \\
\hline \multicolumn{11}{|c|}{ 2002: Vine structure treatment ${ }^{\mathrm{i}}$} \\
\hline Bush vines & $\begin{array}{l}15.49 \mathrm{a} \\
( \pm 1.08)\end{array}$ & $\begin{array}{l}171.47 \mathrm{~b} \\
( \pm 5.97)\end{array}$ & $\begin{array}{c}5.91 \mathrm{a} \\
( \pm 0.34)\end{array}$ & $\begin{array}{l}17.49 \mathrm{~b} \\
( \pm 0.71)\end{array}$ & $\begin{array}{c}2.36 \mathrm{a} \\
( \pm 0.26)\end{array}$ & $\begin{array}{l}212.25 \mathrm{a} \\
( \pm 6.67)\end{array}$ & $\begin{array}{l}25.23 \mathrm{a} \\
( \pm 1.24)\end{array}$ & $\begin{array}{l}35.06 \mathrm{a} \\
( \pm 1.87)\end{array}$ & $\begin{array}{l}102.15 \mathrm{~b} \\
( \pm 6.88)\end{array}$ & $\begin{array}{l}652.08 \mathrm{~b} \\
( \pm 13.26)\end{array}$ \\
\hline Trellised vines & $\begin{array}{l}10.44 \mathrm{~b} \\
( \pm 1.04)\end{array}$ & $\begin{array}{l}190.10 \mathrm{a} \\
( \pm 6.37)\end{array}$ & $\begin{array}{c}5.30 \mathrm{a} \\
( \pm 0.25)\end{array}$ & $\begin{array}{l}19.40 \mathrm{a} \\
( \pm 0.73)\end{array}$ & $\begin{array}{c}1.72 \mathrm{a} \\
( \pm 0.25)\end{array}$ & $\begin{array}{l}227.13 \mathrm{a} \\
( \pm 7.10)\end{array}$ & $\begin{array}{l}21.01 \mathrm{~b} \\
( \pm 1.20)\end{array}$ & $\begin{array}{l}30.25 \mathrm{a} \\
( \pm 1.80)\end{array}$ & $\begin{array}{l}137.39 \mathrm{a} \\
( \pm 6.79)\end{array}$ & $\begin{array}{r}707.95 \mathrm{a} \\
( \pm 13.43)\end{array}$ \\
\hline \multicolumn{11}{|c|}{ 2003: Vine structure treatment ${ }^{\mathrm{i}}$} \\
\hline Bush vines & $\begin{array}{r}13.29 \mathrm{a} \\
( \pm 1.06)\end{array}$ & $\begin{array}{l}177.46 \mathrm{a} \\
( \pm 4.88)\end{array}$ & $\begin{array}{c}0.93 \mathrm{a} \\
( \pm 0.11)\end{array}$ & $\begin{array}{r}16.35 \mathrm{a} \\
( \pm 0.44)\end{array}$ & $\begin{array}{c}1.49 \mathrm{a} \\
( \pm 0.16)\end{array}$ & $\begin{array}{c}209.51 \mathrm{a} \\
( \pm 5.22)\end{array}$ & $\begin{array}{l}10.13 \mathrm{a} \\
( \pm 0.33)\end{array}$ & $\begin{array}{l}13.70 \mathrm{a} \\
( \pm 0.47)\end{array}$ & $\begin{array}{l}120.31 \mathrm{a} \\
( \pm 9.20)\end{array}$ & $\begin{array}{l}657.44 \mathrm{a} \\
( \pm 9.55)\end{array}$ \\
\hline Trellised vines & $\begin{array}{c}9.13 \mathrm{~b} \\
( \pm 0.47)\end{array}$ & $\begin{array}{l}174.30 \mathrm{a} \\
( \pm 4.20)\end{array}$ & $\begin{array}{c}0.75 \mathrm{a} \\
( \pm 0.11)\end{array}$ & $\begin{array}{c}15.80 \mathrm{a} \\
( \pm 0.39)\end{array}$ & $\begin{array}{c}1.31 \mathrm{a} \\
( \pm 0.12)\end{array}$ & $\begin{array}{c}201.29 \mathrm{a} \\
( \pm 4.64)\end{array}$ & $\begin{array}{c}7.70 \mathrm{~b} \\
( \pm 0.27)\end{array}$ & $\begin{array}{l}12.31 b \\
( \pm 0.47)\end{array}$ & $\begin{array}{l}132.43 \mathrm{a} \\
( \pm 9.19)\end{array}$ & $\begin{array}{l}666.53 \mathrm{a} \\
( \pm 9.55)\end{array}$ \\
\hline
\end{tabular}

${ }^{\mathrm{a}} \mathrm{mg} / \mathrm{L}$ unless otherwise noted; most means were adjusted for grape sugar content using covariate analysis except for caftaric, caffeic, coutaric and total phenolic acid contents in 2002 and 2003, non-coloured polymers and total monomers contents in 2002 and gallic acid, $p$-coumaric acid and (+)-catechin content in 2003 ; ${ }^{\mathrm{b}}$ mg $p$-coumaric acid equivalents $/ \mathrm{L} ;{ }^{\mathrm{c}}$ sum of phenolic group content; ${ }^{\mathrm{d}} \mathrm{mg}(+)$-catechin equivalents/L; ${ }^{\mathrm{e}}$ sum of all quantified monomeric phenolic compounds; ${ }^{\mathrm{f}}$ means taken over all vine structure treatments for a specific vintage or climatic region as described in Materials and Methods; ${ }^{\mathrm{g}}$ different letters within a group in a column denote significant differences $(\mathrm{P}<0.05) ;{ }^{\mathrm{h}}$ standard error of mean; ${ }^{\mathrm{i}}$ means taken over all climatic regions and cordon heights for a specific vintage. 
TABLE 9

Antioxidant capacity and objective colour parameters of the 2001, 2002 and 2003 Pinotage wines.

\begin{tabular}{|c|c|c|c|c|c|c|c|c|}
\hline & \multicolumn{3}{|c|}{ Antioxidant capacity $^{\mathrm{a}}$} & \multicolumn{5}{|c|}{ Objective colour parameters } \\
\hline & $\mathrm{TAC}_{\mathbf{M}}{ }^{\mathbf{b}}$ & TAC $_{\text {CAL }}{ }^{c}$ & $\mathrm{TAC}_{\mathbf{R}}{ }^{\mathrm{d}}$ & $C^{*} \mathrm{e}$ & $h^{* \mathrm{f}}$ & $L^{* \mathrm{~g}}$ & $a^{* \mathrm{~h}}$ & $b^{* \mathrm{i}}$ \\
\hline \multicolumn{9}{|c|}{ 2001: Climatic region ${ }^{j}$} \\
\hline Region II & $12.77 \mathrm{a}^{\mathrm{k}}( \pm 0.67)^{\mathrm{l}}$ & na & na & $60.85 \mathrm{a}( \pm 0.76)$ & $15.50 \mathrm{a}( \pm 0.61)$ & $25.62 \mathrm{~b}( \pm 1.85)$ & $58.49 \mathrm{ab}( \pm 0.65)$ & $16.66 \mathrm{a}( \pm 0.72)$ \\
\hline Region III & $13.02 \mathrm{a}( \pm 0.47)$ & na & na & $61.12 \mathrm{a}( \pm 0.50)$ & $14.52 \mathrm{~b}( \pm 0.42)$ & $26.76 \mathrm{~b}( \pm 1.28)$ & $59.17 \mathrm{a}( \pm 0.47)$ & $15.14 \mathrm{a}( \pm 0.51)$ \\
\hline Region IV & $10.44 \mathrm{~b}( \pm 0.42)$ & na & na & $58.41 \mathrm{~b}( \pm 0.52)$ & $13.02 \mathrm{~b}( \pm 0.38)$ & $32.74 \mathrm{a}( \pm 1.15)$ & $56.86 \mathrm{~b}( \pm 0.48)$ & $13.20 \mathrm{~b}( \pm 0.42)$ \\
\hline \multicolumn{9}{|c|}{ 2002: Climatic region ${ }^{\mathrm{j}}$} \\
\hline Region II & $16.11 \mathrm{a}( \pm 0.62)$ & $2.26 \mathrm{a}( \pm 0.05)$ & $14.02 \mathrm{a}( \pm 0.61)$ & $63.44 \mathrm{a}( \pm 0.70)$ & $14.83 \mathrm{a}( \pm 0.71)$ & $30.89 \mathrm{a}( \pm 1.73)$ & $61.23 \mathrm{a}( \pm 0.63)$ & $16.34 \mathrm{a}( \pm 0.81)$ \\
\hline Region III & 15.17 a $( \pm 0.46)$ & $2.13 \mathrm{~b}( \pm 0.04)$ & $13.04 \mathrm{a}( \pm 0.46)$ & $61.02 \mathrm{~b}( \pm 0.66)$ & $13.52 \mathrm{a}( \pm 0.57)$ & $34.58 \mathrm{a}( \pm 1.62)$ & $59.26 \mathrm{~b}( \pm 0.58)$ & $14.36 \mathrm{~b}( \pm 0.64)$ \\
\hline Region IV & $13.77 \mathrm{~b}( \pm 0.31)$ & $2.04 \mathrm{~b}( \pm 0.03)$ & $11.87 \mathrm{~b}( \pm 0.26)$ & $61.24 \mathrm{~b}( \pm 0.63)$ & $14.02 \mathrm{a}( \pm 0.57)$ & $33.34 \mathrm{a}( \pm 1.55)$ & $59.35 \mathrm{~b}( \pm 0.56)$ & $14.77 \mathrm{ab}( \pm 0.65)$ \\
\hline \multicolumn{9}{|c|}{ 2003: Climatic region ${ }^{j}$} \\
\hline Region II & $13.32 \mathrm{a}( \pm 0.50)$ & $1.95 \mathrm{a}( \pm 0.04)$ & $11.37 \mathrm{a}( \pm 0.48)$ & $61.55 \mathrm{a}( \pm 0.87)$ & $14.17 \mathrm{a}( \pm 0.53)$ & $31.64 \mathrm{a}( \pm 1.33)$ & $59.63 \mathrm{a}( \pm 0.21)$ & $15.09 \mathrm{a}( \pm 0.65)$ \\
\hline Region III & $14.02 \mathrm{a}( \pm 0.58)$ & $1.98 \mathrm{a}( \pm 0.04)$ & $12.04 \mathrm{a}( \pm 0.46)$ & $60.08 \mathrm{a}( \pm 1.02)$ & $13.40 \mathrm{a}( \pm 0.62)$ & $31.16 \mathrm{a}( \pm 1.55)$ & $59.32 \mathrm{a}( \pm 0.44)$ & $14.01 \mathrm{a}( \pm 0.75)$ \\
\hline Region IV & $12.69 \mathrm{a}( \pm 0.47)$ & $1.98 \mathrm{a}( \pm 0.03)$ & $10.71 \mathrm{a}( \pm 0.46)$ & $60.57 \mathrm{a}( \pm 0.83)$ & $13.19 \mathrm{a}( \pm 0.51)$ & $33.35 \mathrm{a}( \pm 1.27)$ & $58.97 \mathrm{a}( \pm 0.41)$ & $13.90 \mathrm{a}( \pm 0.62)$ \\
\hline \multicolumn{9}{|c|}{ 2001: Vine structure treatment ${ }^{\mathrm{m}}$} \\
\hline Bush vines & $12.44 \mathrm{a}( \pm 0.52)$ & na & na & $59.51 \mathrm{a}( \pm 0.54)$ & $14.51 \mathrm{a}( \pm 0.46)$ & $27.82 \mathrm{a}( \pm 1.42)$ & $57.64 \mathrm{a}( \pm 0.48)$ & $14.66 \mathrm{a}( \pm 0.44)$ \\
\hline Trellised vines & 11.71 a $( \pm 0.53)$ & na & na & $60.25 \mathrm{a}( \pm 0.48)$ & $14.19 \mathrm{a}( \pm 0.46)$ & $28.93 \mathrm{a}( \pm 1.44)$ & 58.43 a $( \pm 0.43)$ & $14.49 \mathrm{a}( \pm 0.52)$ \\
\hline \multicolumn{9}{|c|}{ 2002: Vine structure treatment ${ }^{\mathrm{m}}$} \\
\hline Bush vines & $15.41 \mathrm{a}( \pm 0.45)$ & $2.08 \mathrm{a}( \pm 0.04)$ & $13.50 \mathrm{a}( \pm 0.41)$ & $61.86 \mathrm{a}( \pm 0.61)$ & $14.96 \mathrm{a}( \pm 0.24)$ & $31.06 \mathrm{~b}( \pm 1.26)$ & $59.74 \mathrm{a}( \pm 0.53)$ & $15.98 \mathrm{a}( \pm 0.28)$ \\
\hline Trellised vines & 14.32 a $( \pm 0.31)$ & $2.17 \mathrm{a}( \pm 0.04)$ & $12.18 \mathrm{~b}( \pm 0.31)$ & $61.93 \mathrm{a}( \pm 0.58)$ & $13.23 \mathrm{~b}( \pm 0.64)$ & $34.81 \mathrm{a}( \pm 1.19)$ & $60.15 \mathrm{a}( \pm 0.50)$ & $14.18 b( \pm 0.74)$ \\
\hline \multicolumn{9}{|c|}{ 2003: Vine structure treatment ${ }^{\mathrm{m}}$} \\
\hline Bush vines & 14.16 a $( \pm 0.40)$ & $1.99 \mathrm{a}( \pm 0.03)$ & $12.17 \mathrm{a}( \pm 0.39)$ & $61.31 \mathrm{a}( \pm 0.73)$ & $14.28 \mathrm{a}( \pm 0.43)$ & 31.10 a $( \pm 1.15)$ & $59.42 \mathrm{a}( \pm 0.25)$ & $15.13 \mathrm{a}( \pm 0.53)$ \\
\hline Trellised vines & $12.53 \mathrm{~b}( \pm 0.40)$ & $1.95 \mathrm{a}( \pm 0.03)$ & $10.58 \mathrm{~b}( \pm 0.39)$ & $60.16 \mathrm{a}( \pm 0.73)$ & $12.90 \mathrm{~b}( \pm 0.43)$ & $33.00 \mathrm{a}( \pm 1.15)$ & $59.17 \mathrm{a}( \pm 0.40)$ & $13.54 \mathrm{~b}( \pm 0.53)$ \\
\hline
\end{tabular}

a antioxidant capacity values for 2003 were adjusted for grape sugar content using covariate analysis; ${ }^{\mathrm{b}}$ total antioxidant capacity in mM Trolox equivalents as measured; $\mathrm{c}$ total antioxidant capacity in mM Trolox equivalents as calculated from the content of monomeric phenolic compounds and their Trolox equivalent antioxidant capacity;

${ }^{\mathrm{d}} \mathrm{TAC}_{\mathrm{R}}=\mathrm{TAC}_{\mathrm{M}}-\mathrm{TAC}_{\mathrm{CAL}} ;{ }^{\mathrm{e}}$ chroma; ${ }^{\mathrm{f}}$ hue angle $\left({ }^{\circ}\right) ;{ }^{\mathrm{g}}$ lightness; ${ }^{\mathrm{h}}$ red/green chromaticity; ${ }^{\mathrm{i}}$ yellow/blue chromaticity; ${ }^{\mathrm{j}}$ means taken over all vine structure treatments for a specific vintage or climatic region as described in Materials and Methods; ${ }^{k}$ different letters within a group in a column denote significant differences $(\mathrm{P}<0.05) ;{ }^{1}$ standard error of mean; ${ }^{\mathrm{m}}$ means taken over all climatic regions and cordon heights for a specific vintage; na $=$ not available.

higher $C^{*}$ when produced from the cooler climate, although the difference was not statistically significant.

\section{Climatic region: Discriminant analysis}

Canonical discriminant analysis was performed to attempt discrimination between the wines from different climatic regions with regard to variables relating to phenolic composition. Forward stepwise variable selection was applied to obtain variables with the highest discriminating power for climatic region for each of the 2002 and 2003 vintages. Sixteen and 18 variables were selected for the 2002 and 2003 vintages, respectively (Figs 5 \& 6). Regions II and III wines can easily be discriminated from region IV wines by the first discriminant function in both vintages, while regions II and III wines are separated by the second discriminant function with minor overlapping. More overlapping between regions II and III wines occurs during 2003. During 2002, the caftaric acid, malvidin-3-Glc-Ac and coloured polymer (HPLC) contents had the highest positive correlations to the first discriminant function, while the coutaric acid, $p$-coumaric acid and malvidin-3-Glc contents contributed greatly in the negative direction of the first discriminant function (data not shown). The

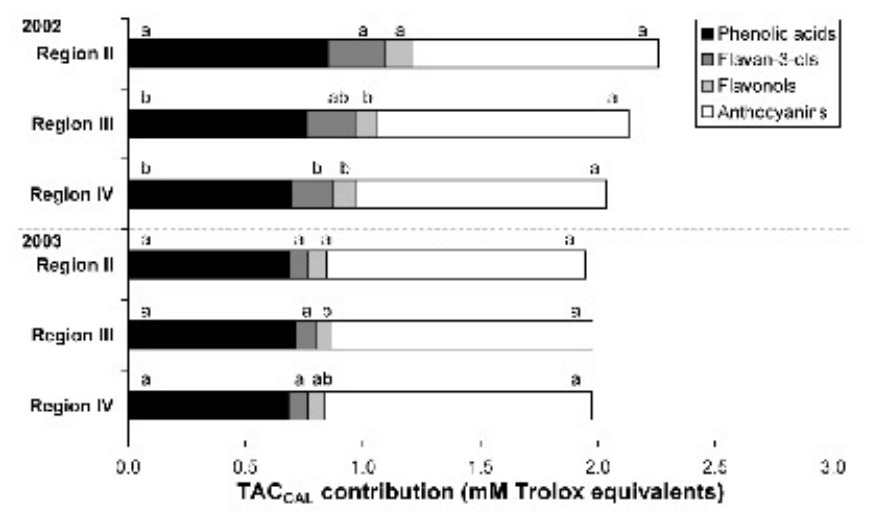

FIGURE 4

Phenolic group contributions to the calculated total antioxidant capacity (TAC$\mathrm{CAL}$ ) of wines from different climatic regions (as described in Materials and Methods) [different letters for the contribution of a specific phenolic group in the same year denote significant differences $(\mathrm{P}<0.05)]$. 
second discriminant function for the 2002 wines was mostly controlled by the caftaric acid and malvidin-3-Glc-Ac contents in the positive direction and by the malvidin-3-Glc content in the negative direction (data not shown). Among the variables contributing most to the first discriminant function for the 2003 wines were the positively-correlated delphinidin-3-Glc-Ac, malvidin-3-Glc and coutaric acid contents and the negatively-correlated malvidin-3-Glc-Ac and delphinidin-3-Glc contents (data not shown). The coutaric acid, (+)-catechin and delphinidin-3-Glc-Ac contents made the greatest positive contribution to the second discriminant function for the 2003 wines, while the greatest negative contributions were made by the caftaric acid, procyanidin B1 and vitisin A contents (data not shown).

\section{Vine structure: Effect on grape sugar content and phenolic composition}

The grape sugar content did not differ significantly between vine structure treatments for any of the vintages (Table 5).

Trunk height had a significant effect on the phenolic composition of the wines in a small number of cases only (see Table 10). Bush vines with a trunk height of $20 \mathrm{~cm}$ produced wines with a higher total phenol content than the 30-cm treatment for the 2002 vintage. Individual phenolic composition was affected by trunk height of wines produced in 2003, with the $20-\mathrm{cm}$ bush vine treatment resulting in wines with significantly lower delphinidin-3-

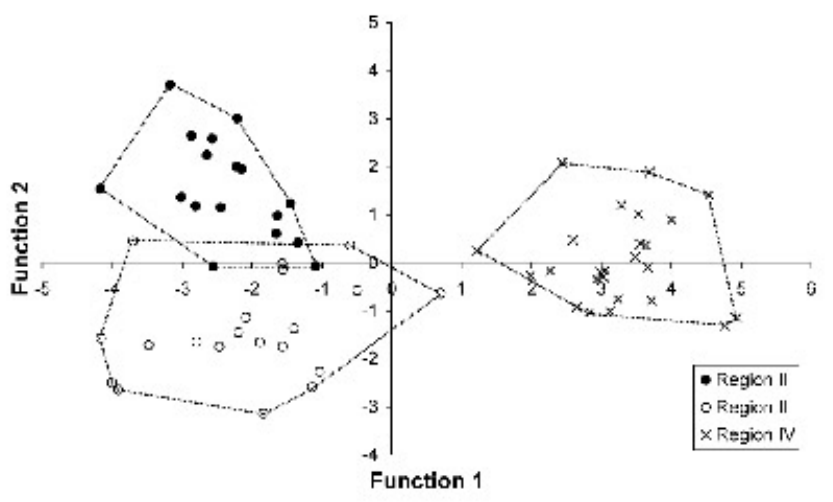

FIGURE 5

Distribution of the 2002 Pinotage wines in the plane defined by the first two discriminant functions according to climatic regions (as described in Materials and Methods) (variables selected = petunidin-3-Glc, peonidin-3-Glc, malvidin-3-Glc, vitisin A, malvidin-3-Glc-Ac, coloured polymer (HPLC), quercetin-3-Glc, kaempferol, isorhamnetin, gallic acid, caftaric acid, caffeic acid, coutaric acid, $p$ coumaric acid, (+)-catechin and non-coloured polymer contents, Glc = glucoside,

$$
\text { Glc-Ac = acetylglucoside) } \text {. }
$$

Glc content and significantly higher caffeic and $p$-coumaric acid contents compared to the $30-\mathrm{cm}$ bush vine treatment. For the trellised vines, only the coloured polymer content (HPLC) of the 2003 wines was affected, with a higher content for wines from the $60-\mathrm{cm}$ treatment compared to the $30-\mathrm{cm}$ treatment. Due to the relatively minor influence of trunk height on the phenolic composition of the wines, data for wines produced from bush and trellised vines with averages taken over the different trunk height treatments are presented in Table 5 to 9.

The total phenol content was lower for wines from trellised vines than from bush vines for all the vintages, although this trend was only significant for the 2003 vintage (Table 5).

Vine structure treatment had little effect on the anthocyanin content ( $\mathrm{pH}$ shift) of the wines (Table 5). Only the polymeric anthocyanin content (pH shift) of the 2002 wines was affected, with trellised vines resulting in wines with a lower content. Considering individual anthocyanins, vine structure treatment did not affect the peonidin-3-Glc, delphinidin-3-Glc-Ac, vitisin A and petunidin-3-Glc-Ac contents of the 2002 wines, and the delphinidin-3-Glc, petunidin-3-Glc, delphinidin-3-Glc-Ac, vitisin A and petunidin-3-Glc-Ac contents of the 2003 wines (Table 6). Apart from peonidin-3-Glc-Ac (2002 and 2003 wines) and peonidin-3-Glc (2003 wines) that were increased in the wine by using grapes from bush vines, the contents of other anthocyanins,

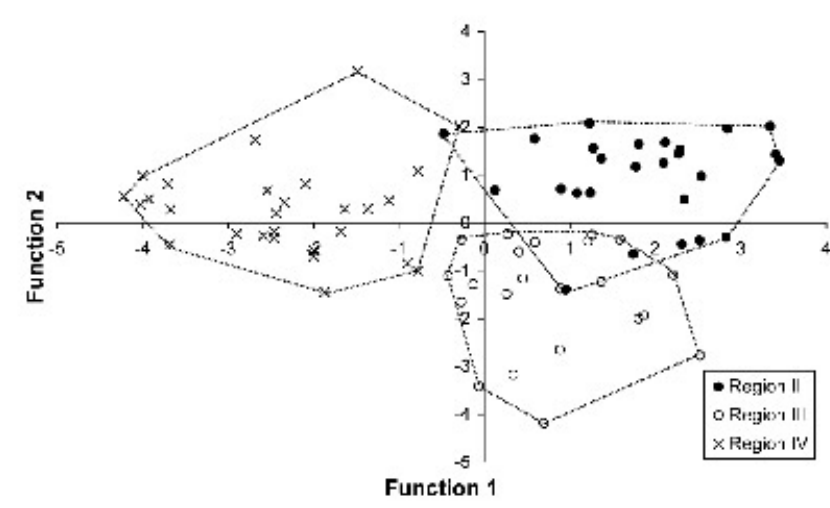

FIGURE 6

Distribution of the 2003 Pinotage wines in the plane defined by the first two discriminant functions according to climatic regions (as described in Materials and Methods) (variables selected = delphinidin-3-Glc, peonidin-3-Glc, malvidin-3-Glc, delphinidin-3-Glc-Ac, vitisin A, peonidin-3-Glc-Ac, malvidin-3-Glc-Ac, malvidin-3-Glc-Coum, coloured polymer (HPLC), unknown flavonol, quercetin-3-Glc, quercetin-3-Rham, gallic acid, caftaric acid, caffeic acid, coutaric acid, (+)-catechin and procyanidin $\mathrm{B} 1$ contents, Glc $=$ glucoside, Glc-Ac $=$ acetylglucoside, p-coumaroyl-glucoside, Rham = rhamnoside).

\section{TABLE 10}

Effect of cordon height on the phenolic composition ${ }^{\mathrm{a}}$ of the 2002 and 2003 Pinotage wines.

\begin{tabular}{|c|c|c|c|c|c|c|}
\hline \multirow[b]{2}{*}{ Vine structure treatment } & \multirow[b]{2}{*}{ Trunk height } & \multirow{2}{*}{$\begin{array}{c}2002 \\
\text { Total phenols }^{\mathrm{b}}\end{array}$} & \multicolumn{4}{|c|}{2003} \\
\hline & & & Dp-3-Glc-Ac & Coloured polymers ${ }^{\mathrm{c}}$ & Caffeic acid & $p$-Coumaric acid \\
\hline \multirow[t]{2}{*}{ Bush vines } & $20 \mathrm{~cm}$ & $1843.5 \mathrm{a}^{\mathrm{d}}( \pm 60.7)^{\mathrm{e}}$ & $12.83 \mathrm{~b}( \pm 1.12)$ & $12.00 \mathrm{~b}( \pm 0.54)$ & $1.21 \mathrm{a}( \pm 0.16)$ & $1.89 \mathrm{a}( \pm 0.24)$ \\
\hline & $30 \mathrm{~cm}$ & 1671.3 b $( \pm 82.9)$ & 15.59 a $( \pm 0.94)$ & $13.43 \mathrm{~b}( \pm 0.67)$ & $0.66 \mathrm{~b}( \pm 0.12)$ & $1.11 \mathrm{~b}( \pm 0.17)$ \\
\hline \multirow[t]{2}{*}{ Trellised vines } & $30 \mathrm{~cm}$ & $1709.6 \mathrm{ab}( \pm 55.28)$ & 11.64 b ( \pm 0.92$)$ & $13.87 \mathrm{~b}( \pm 0.76)$ & $0.68 \mathrm{~b}( \pm 0.13)$ & $1.36 \mathrm{~b}( \pm 0.19)$ \\
\hline & $60 \mathrm{~cm}$ & $1748.5 \mathrm{ab}( \pm 52.18)$ & $13.83 \mathrm{ab}( \pm 1.24)$ & $16.70 \mathrm{a}( \pm 1.07)$ & $0.83 \mathrm{ab}( \pm 0.18)$ & $1.26 \mathrm{~b}( \pm 0.15)$ \\
\hline
\end{tabular}

${ }^{\mathrm{a}} \mathrm{mg} / \mathrm{L}$ unless otherwise noted; ${ }^{\mathrm{b}} \mathrm{mg}$ gallic acid equivalents $/ \mathrm{L} ;{ }^{\mathrm{c}} \mathrm{mg}$ malvidin-3-Glc equivalents/L; ${ }^{\mathrm{d}}$ different letters in a column denote significant differences $(\mathrm{P}<0.05)$;

e standard error of mean; Dp = delphinidin; Glc-Ac = acetylglucoside. 
monomeric anthocyanins (HPLC) and coloured polymers (HPLC) (2003 only) were higher in trellised vine wines.

The flavonol content of the 2002 wines was not affected by the vine structure treatment, while only the quercetin-3-rham and quercetin contents of the 2003 wines from bush vines were significantly higher than those from trellised vines (Table 7).

The vine structure treatment did not affect the total phenolic acid, caffeic acid or $p$-coumaric acid content of wines, for either of the vintages (Table 8). The gallic acid content of wines produced from bush vines was significantly higher than that of wines produced from trellised vines for both vintages. The caftaric and coutaric acid contents, on the other hand, were lower for wines from bush vines compared to trellised vines for the 2002 vintage, with no effect observed for the 2003 wines.

Bush vines resulted in wines with a higher total flavan-3-ol content (DAC) than trellised vines for the 2003 vintage only (Table 5). When using HPLC analysis, this trend was confirmed for the 2003 wines, and the same trend was also observed for the 2002 wines (Table 8). In addition, bush vines gave wines with higher (+)-catechin contents for both vintages and procyanidin B1 contents for the 2003 vintage. On the other hand, the 2002 wines produced from bush vines had a lower non-coloured polymer content compared to wines produced from trellised vines, but no effect was observed for the 2003 wines.

The total monomer content (HPLC) was higher for wines from trellised vines than from bush vines of the 2002 vintage, with no effect observed for the 2003 vintage (Table 8).

\section{Vine structure: Effect on antioxidant capacity}

Trunk height did not affect the $\mathrm{TAC}_{\mathrm{M}}, \mathrm{TAC}_{\mathrm{CAL}}$ or $\mathrm{TAC}_{\mathrm{R}}$ of the wines (data not shown). Wines produced from bush vines had higher $\mathrm{TAC}_{\mathrm{M}}$ values than those produced from trellised vines (all vintages), although this trend was only significant for the 2003 wines (Table 9). The $\mathrm{TAC}_{\mathrm{CAL}}$, however, was not affected by the different vine structure treatments for either the 2002 or 2003 vintages, but the $\mathrm{TAC}_{\mathrm{R}}$ of bush vine wines was higher than that of

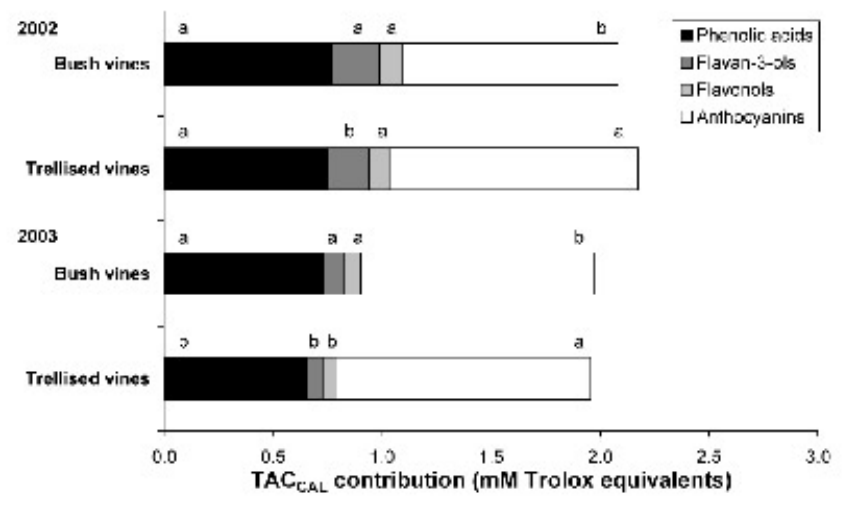

FIGURE 7

Phenolic group contributions to the calculated total antioxidant capacity (TAC$\mathrm{CAL}$ ) of wines from different vine structure treatments [different alphabet letters for the contribution of a specific phenolic group in the same year denote significant differences $(\mathrm{P}<0.05)]$. wines produced from trellised vines of both vintages. For the 2002 wines, the lower anthocyanin contribution to the $\mathrm{TAC}_{\mathrm{CAL}}$ of the bush vine wines was balanced out by the higher contribution of flavan-3-ol content, while for the 2003 wines the lower anthocyanin contribution was cancelled out by the higher contributions of phenolic acids, flavan-3-ols and flavonols (Fig. 7).

\section{Vine structure: Effect on objective colour parameters}

Trunk height did not significantly affect any of the objective colour parameters of the wines (data not shown). No significant differences in objective colour parameters between wines from bush and trellised vines were observed for the 2001 vintage (see Table 9). The 2002 and 2003 wines, however, showed significantly higher $h^{*}$ and $b^{*}$ values for wines from bush vines, compared to wines from trellised vines, while the $a^{*}$ and $C^{*}$ values were not significantly affected by vine structure treatment. For the 2002 vintage, the $L^{*}$ value of wine from trellised vines was significantly higher than that of wines from bush vines.

\section{Vine structure: Discriminant analysis}

Canonical discriminant analysis with forward stepwise variable selection was also performed to attempt discrimination between the wines produced from different vine structure treatments using variables relating to phenolic composition. Fifteen and 16 variables were selected in the 2002 and 2003 vintage, respectively (Figs 8 \& 9). Wines from vines with different trunk heights could not be discriminated for either of the two vintages. When the first two discriminant functions arising in the canonical discriminant analysis of the 2002 vintage are plotted for bush and trellised vine wines, there is very little overlapping. This indicates fairly good discrimination between the vine structure treatments. For the first discriminant function of the 2002 vintage data, the malvidin-3Glc and gallic acid contents were highly positively correlated, while the malvidin-3-Glc-Coum, non-coloured polymer and delphinidin-3-Glc-Ac contents were highly negatively correlated (data not shown). The second discriminant function was highly influenced in the positive direction by the quercetin and petuni-

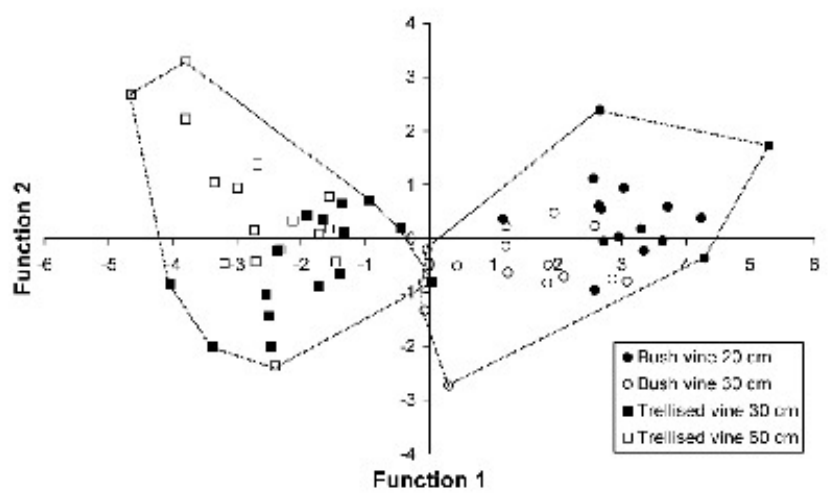

FIGURE 8

Distribution of the 2002 Pinotage wines in the plane defined by the first two discriminant functions according to vine structure treatment (variables selected $=$ delphinidin-3-Glc, malvidin-3-Glc, delphinidin-3-Glc-Ac, petunidin-3-Glc-Ac, peonidin-3-Glc-Ac, malvidin-3-Glc-Coum, coloured polymer (HPLC), quercetin3-Glc, myricetin, quercetin, kaempferol, gallic acid, caftaric acid, (+)-catechin and non-coloured polymer contents, Glc = glucoside, Glc-Ac = acetylglucoside, Glc-Coum $=p$-Coumaroyl-glucoside) 
din-3-Glc contents, while the delphinidin-3-Glc-Ac and kaempferol contents were the highest contributors in the negative direction (data not shown). For data from the 2003 vintage, the discrimination between wines from bush and trellised vines is less pronounced, with more overlapping. Variables with high correlation to the first discriminant function in the 2003 vintage were the coloured polymer (HPLC) (positive), peonidin-3-Glc (negative) and malvidin-3-Glc-Ac (negative) contents, while for the second discriminant function the malvidin-3-Glc-Coum and malvidin-3-Glc contents were the greatest contributors in the positive and negative direction, respectively (data not shown).

\section{DISCUSSION}

Pinotage wines from the first vintage (2001) were analysed for phenolic composition using spectrophotometric assays, antioxidant capacity and objective colour parameters. Since this preliminary study showed that climatic region and vine structure treatment significantly affected wine properties, wines prepared during the subsequent two vintages were analysed more extensively using HPLC analysis to identify trends for individual phenolic compound content.

\section{Effect of grape maturity}

In this study it was attempted to harvest grapes within a window of $2^{\circ} \mathrm{B}$, i.e. between 24 and $26^{\circ} \mathrm{B}$, as it may affect the composition and characteristics of the resulting wines. Problems such as widely dispersed vineyard sites and the dependence of ripeness development near the critical level on local daily weather phenomena, such as heatwaves and rain, hampered the harvesting of grapes at the same sugar content. Subsequently, $15 \%$ of treatments were harvested too early or too late, i.e. with a grape sugar content $<24^{\circ} \mathrm{B}$ or $>26^{\circ} \mathrm{B}$. The average grape sugar content did not, however, differ significantly between the vintages or between climatic regions and vine structure treatments in the respective vintages. Covariance analysis with grape sugar content as covariate was performed, however, and the means for affected variables were adjusted.

\section{Vintage-related variations}

Vintage-related variations in terms of phenolic composition and TAC are presumably due to variation in weather patterns for the respective years. Cooler night temperatures during the berry ripening period in 2003 caused lower average February temperatures in the respective climatic regions, compared to 2002 (unpublished data). This would explain the variations in the contribution of monomeric phenolic compounds to the $\mathrm{TAC}_{\mathrm{M}}$, represented by $\mathrm{TAC}_{\mathrm{CAL}}$, being lower for the 2003 wines compared to the 2002 wines. This trend is especially due to lower contents of high potency compounds, such as (+)-catechin, procyanidin B1(De Beer et al., 2006), and most of the anthocyanin monoglucosides. This is in agreement with the findings of Mori et al. (2005), showing that the concentration of anthocyanins in Pinot Noir berry skins was decreased by lower night temperatures. The $\mathrm{TAC}_{\mathrm{R}}$ was also lower for the 2003 wines compared to the 2002 wines, due to changes in unknown compounds or oligomers with less than five subunits as the non-coloured polymer content (polymers with five subunits or larger) showed no significant differences between vintage wines. The lower $\mathrm{TAC}_{\mathrm{M}}$ of the 2003 wines is therefore mostly due to decreased antioxidant capacity of monomeric phenolic compounds and small, unknown compounds.

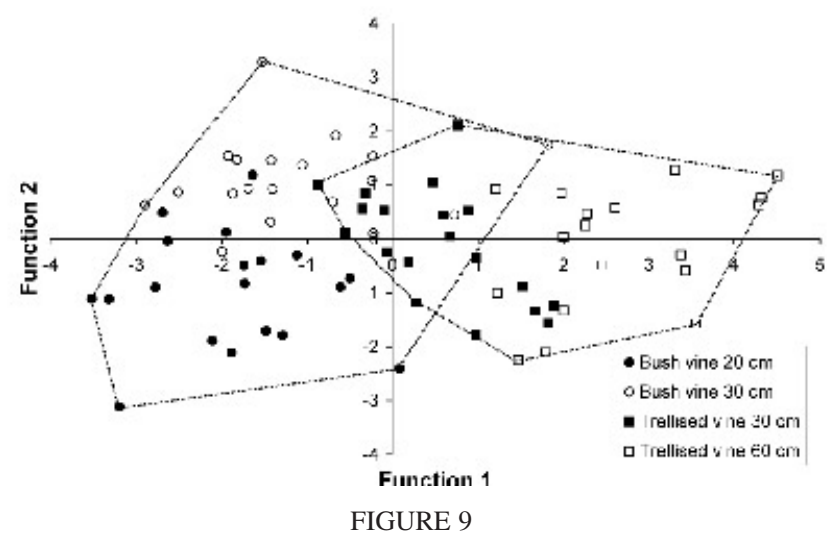

Distribution of the 2003 Pinotage wines in the plane defined by the first two discriminant functions according to vine structure treatment (variables selected = peonidin-3-Glc, malvidin-3-Glc, vitisin A, petunidin-3-Glc-Ac, peonidin-3-Glc, malvidin-3-Glc-Ac, malvidin-3-Glc-Coum, coloured polymer (HPLC), quercetin3-Glc, quercetin-3-Rham, myricetin, isorhamnetin, caffeic acid, $p$-coumaric acid, $(+)$-catechin and procyanidin B1 contents, Glc $=$ glucoside, Glc-Ac $=$ acetylglucoside, Glc-Coum = $p$-Coumaroyl-glucoside, Rham $=$ rhamnoside $)$.

The average wine hues for the different vintages were a similar magenta-red hue, although hues of individual wines in each vintage ranged from red-magenta through magenta-red to pure red (data not shown).

The 2001 wines were darker (lower $L^{*}$ ), with lower $a^{*}$ values than the 2002 and 2003 wines (see Table 1). Their anthocyanin content explains their darker colour, but not their lower $a^{*}$ values and unchanged $C^{*}$ values. This was unexpected, as the higher anthocyanin content should lead to increased $C^{*}$ and $a^{*}$ values and decreased $L^{*}$ values. However, inversion was observed with $C^{*}$ and $a^{*}$ values, especially at lower $L^{*}$ values, corresponding to very dark wines. This phenomenon, previously reported for darkcoloured beverages (Eagerman et al., 1973), port (Bakker et al., 1986), young red wines (Almela et al., 1995) and dark-coloured anthocyanin solutions (Gonnet, 1999), is related to the difficulty of photocells to adjust to low luminosity situations. The use of cells with pathlength shorter than $5 \mathrm{~mm}$ would be advisable. $L^{*}$ values for the 2001 wines were generally lower than for the 2002 wines, with more wines having $L^{*}$ values where inversion occurred, explaining this discrepancy.

The higher colour saturation (higher $C^{*}$ ) of the 2002 wines compared to the 2003 wines could possibly be due to higher contents of anthocyanin monoglucosides with high specific absorptivity, such as petunidin-3-Glc (Cabrita et al., 2000). Lower contents of some acylated anthocyanins, which generally have lower absorptivity (Giusti et al., 1999), should affect the colour saturation to a lesser extent. The higher phenolic acid and flavan-3-ol contents observed for the 2002 wines compared to the 2003 wines could also have increased the colour saturation due to an enhanced co-pigmentation effect with anthocyanins (Gonnet, 1999). Other factors that can play a role are co-pigment to pigment ratios (Gonnet, 1999) and $\mathrm{pH}$ (Heredia et al., 1998).

\section{Effect of climatic region}

Cooler ambient temperatures tend to favour accumulation of anthocyanins in berry skins and the resulting wines (Bergqvist et al., 2001; Mateus et al., 2002; Miguel-Tabares et al., 2002; Spayd 
et al., 2002) as also found in this study for Pinotage wines. Sunlight exposure, however, increases anthocyanin concentration in grapes (Kliewer, 1970; Crippen \& Morrison, 1986; Spayd et al., 2002). As sunlight exposure could differ between climatic regions, vineyard sites and individual canopies, this effect cannot be separated from other climatic factors in the present study.

Mateus et al. (2001) reported that higher average temperatures during ripening produced berries and resulting Port wines with higher flavan-3-ol content. The opposite trend was observed in the present study during 2002.

Previous reports on flavonol accumulation in grape berries focussed on the effect of sunlight exposure (Haselgrove et al., 2000; Downey et al., 2004), which does not necessarily coincide with the effect of temperature. In the present study, no consistent effects of climatic region on flavonol content were observed.

Previous studies did not include the effect of climate on the phenolic acids content. In the present study, different results were obtained for the two vintages, suggesting that more vintages are needed to clarify effects. Canonical discriminant analysis confirmed the results of analysis of variance for the phenolic composition of wines from different climatic regions.

The $\mathrm{TAC}_{\mathrm{M}}$ values for wines from different climatic regions can be explained by their total phenol contents. A relationship between TAC and total phenol content of wines has previously been shown (Landrault et al., 2001; De Beer et al., 2003). The trend for $\mathrm{TAC}_{\mathrm{CAL}}$ of the 2002 wines could mainly be explained by a higher contribution by caftaric acid, (+)-catechin, procyanidin B1 and quercetin for region II wines, compared to wines from the other regions. These compounds have high antioxidant potency (De Beer et al., 2006). The caftaric acid content was much higher for wines from the cooler climatic region, thus substantially increasing its relative contribution to the $\mathrm{TAC}_{\mathrm{CAL}}$ despite its relatively low antioxidant potency (De Beer et al., 2006). The antioxidant contributions of both monomeric phenolic compounds $\left(\mathrm{TAC}_{\mathrm{CAL}}\right)$ and unknown compounds $\left(\mathrm{TAC}_{\mathrm{R}}\right)$ were higher for wines from cooler regions compared to warmer regions, as no significant differences in non-coloured polymer content were observed. The coloured polymer content (HPLC) was higher for region IV wines compared to the wines from regions II and III and would thus negate some of the effect of the decreasing concentrations of other compounds in these wines. During 2003, however, no significant difference in $\mathrm{TAC}_{\mathrm{CAL}}$ was observed between wines from different climatic regions, due to the nonsignificant differences in contributions by phenolic acids, flavan3-ols or anthocyanins. During both 2002 and 2003, the content of some anthocyanin monoglucosides increased in wines as the climatic region became progressively cooler, while the opposite was true for some acylated anthocyanins. For the 2002 vintage, the total contribution of anthocyanins to the $\mathrm{TAC}_{\mathrm{CAL}}$ for the wines from the cooler climatic region was higher than for the wines from the warmer climatic region. Many phenolic compounds that were not measured and other compounds of low or high MW, such as proteins, peptides, polysaccharides and possibly others, could also contribute to the TAC of Pinotage wines, as discussed in De Beer et al. (2006).

The cooler climatic region produced wines that were generally darker (lower $L^{*}$ ) with a higher colour saturation (higher $C^{*}$ ) and a higher $h^{*}$, namely a magenta-red hue closer to pure red, due to a higher $b^{*}$ compared to wines from the warmer regions during 2001. However, in 2002 the region II wines had higher colour saturation (higher $C^{*}$ ) due to higher $a^{*}$ and lower $b^{*}$ values, and no significant difference in lightness $\left(L^{*}\right)$. The average hue for the 2002 wines from all the climatic regions was in the magenta-red range. The higher $L^{*}$ and $C^{*}$ values observed for the 2001 wines from the cool climatic region is attributed to higher monomeric anthocyanin contents. On the other hand, the higher $C^{*}$ for the 2002 wines from the cooler region can be attributed to increased anthocyanin monoglucoside contents. The higher co-pigment factor contents, e.g. phenolic acids, flavonols and/or flavan-3-ols, for wines from cool regions, compared to warm region wines for the 2001 and 2002 vintage would further explain the higher $C^{*}$ values for these wines (Gonnet, 1999). On the other hand, the higher co-pigment factor contents in the 2001 wines from region II caused a higher $h^{*}$ compared to wines from region III and IV, while the opposite was true for the 2002 wines. This apparent discrepancy is similar to both "blueing" (higher $h^{*}$ ) and "yellowing" (lower $h^{*}$ ) effects for solutions containing cyanin and rutin, with increasing co-pigment content, as described by Gonnet (1999). During 2003, no significant differences in total phenolic acid, total flavan-3-ol and monomeric anthocyanin contents for wines from different climatic regions were observed, while only differences in some flavonols occurred. These results explain the lack of significant differences between objective colour parameters of wines from different climatic regions. The average hue for the 2003 wines from the different climatic regions was in the magenta-red range.

\section{Effect of vine structure}

Vine structure treatments had contrasting effects on the polymeric anthocyanin content ( $\mathrm{pH}$ shift) and the coloured polymer content (HPLC) for several reasons. The polymer peak in the HPLC chromatograms represents only polymers of five or more subunits (Peng et al., 2002), whereas polymeric anthocyanins of less than five subunits will be included in the $\mathrm{pH}$ shift assay measurement. Furthermore, the monomeric anthocyanins will contribute a small amount to the polymeric pigment content due to residual absorbance at $\mathrm{pH} 4.9$ in the $\mathrm{pH}$ shift assay (Cabrita et al., 2000). It was previously reported that vine structure had no effect on berry skin anthocyanin content (Tamborra et al., 2003; Wolf et al., 2003). In contrast, the present study showed significant differences in the concentrations of several individual anthocyanins in Pinotage wines, especially peonidin-3-Glc-Ac which was higher for wines from bush vines and malvidin-3-Glc, malvidin-3Glc-Ac and malvidin-3-Glc-Coum which were higher for wines from trellised vines.

Similarly, no significant differences in berry flavonol content between berries from bush and trellised vines were shown by Tamborra et al. (2003), but the present study showed significant differences in the concentrations of quercetin and quercetin-3Rham, although only for the 2003 wines. Higher flavonol concentrations for wines from bush vines should, however, not be due to differences in sunlight exposure between vine structure treatments, as both bush and trellised vines had optimal canopy management to ensure similar canopy densities in terms of leaf layers.

On the other hand, Tamborra et al. (2003) showed a similar trend for phenolic acid content, namely lower cis- and trans-caf- 
taric acid and lower cis- and trans-coutaric acid in grape skins for grapes from bush vines compared to trellised vines, as observed in the present study for the 2002 wines.

The effect of vine structure on the flavan-3-ol content of grapes or wines has not been reported to date. Wines from bush vines were found to have higher (+)-catechin and procyanidin B1 concentrations, but a lower non-coloured polymer content than wines from trellised vines. The results of the analysis of variance were supported by the canonical discriminant analysis taking a number of phenolic content parameters into account.

The differences in $\mathrm{TAC}_{\mathrm{M}}$ for the vine structure treatments can be explained by their difference in total phenol content as was observed for different climatic regions, with both parameters only significant for the 2003 vintage. For the 2002 vintage, the lower anthocyanin contribution to the $\mathrm{TAC}_{\mathrm{CAL}}$ of the bush vine wines, which is especially due to a much lower content of anthocyanin monoglucosides and acylated malvidin derivatives, was balanced out by the higher contribution of the high antioxidant potency flavan-3-ols, specifically (+)-catechin (De Beer et al., 2006). In 2003 the lower anthocyanin contribution, mostly due to substantially lower contents of malvidin-3-Glc and its acylated derivatives, was cancelled out by higher contributions by phenolic acids, flavan-3ols and flavonols, especially due to the higher contents of the high potency antioxidant compounds, gallic acid, (+)-catechin and procyanidin B1 (De Beer et al., 2006). The increased $\mathrm{TAC}_{\mathrm{M}}$ of wines from bush vines compared to those from trellised vines in 2002 and 2003 are thus mostly due to unknown compounds, especially since both the coloured and non-coloured polymer contents were lower for wines from bush vines.

Results for the objective colour parameters of the 2002 and 2003 wines indicate that wines produced from bush vines were generally less magenta (higher $h^{*}$ ) due to higher $b^{*}$ values than those produced from trellised vines. Higher $h^{*}$ and $b^{*}$ values for wines from bush vines for the 2002 vintage are attributed to their higher co-pigment content (gallic acid and (+)-catechin) and lower monomeric anthocyanin content than wines from trellised vines, which changes the co-pigment to pigment ratio (Gonnet, 1999). These results, as well as their higher polymeric anthocyanin content ( $\mathrm{pH}$ shift), explain their darker colour (lower $L^{*}$ ). It did however not affect the $a^{*}$ values. Inversion could be a factor in this case. In 2003, the higher $h^{*}$ and $b^{*}$ values for wines from bush vines compared to wines from trellised vines were due to higher quercetin and quercetin-3-Rham contents. Higher gallic acid, flavan-3-ol and flavonol contents, by contributing to co-pigmentation, cancelled out the negative effect of a lower monomeric anthocyanin content on the $L^{*}$ values of the 2003 wines from bush vines compared to the 2003 wines from trellised vines.

\section{CONCLUSIONS}

The phenolic composition, antioxidant capacity and objective colour parameters of Pinotage wines were significantly affected by climatic region and vine structure treatments, although the trunk height of the vine had few significant effects. In general, the warmer climatic regions produced lighter coloured wines with lower TAC, mainly due to lower total phenol content. This trend could be partly explained by the variation in phenolic composition among wines from the different climatic regions, although unknown compounds are mostly responsible for differences in
TAC. Wines from bush vines were generally darker, with slightly higher TAC, than wines from trellised vines, although the latter wines had higher monomeric anthocyanin concentrations. This was also due to increased total phenol content, although some phenolic compounds were present in lower quantities. Once again, unknown compounds contributed significantly to the differences in TAC between wines from different vine structure treatments. Canonical discriminant analysis confirmed the observations from analysis of variance for individual parameters by enabling discrimination between wines from different climatic regions and vine structure treatments (bush versus trellised vines) based on a large number of parameters. Cultivation of Pinotage bush vines in cooler climatic regions is recommended when a higher TAC is a requirement. The effect of viticultural manipulations on the sensory quality of Pinotage wines is also important and will be addressed in a future paper. Some vintage-related variation was observed, which indicates that wines from more vintages need to be analysed in order to verify the results obtained in the present study.

\section{LITERATURE CITED}

Almela, L., Javaloy, S., Fernández-López, J.A. \& López-Roca, J.M., 1995. Comparison between the tristimulus measurements Yxy and $L * a * b *$ to evaluate the colour of young red wines. Food Chem. 53, 321-327.

Amerine, M.A. \& Winkler, A.J., 1944. Composition and quality of musts and wines of California grapes. Hilgardia 15, 493-675.

Bakker, J., Bridle, P. \& Timberlake, C.F., 1986. Tristimulus measurements (CIELAB 76) of port wine colour. Vitis 25, 67-78.

Bergqvist, J., Dokoozlian, N. \& Ebisuda, N., 2001. Sunlight exposure and temperature effects on berry growth and composition of Cabernet Sauvignon and Grenache in the Central San Joaquin Valley of California. Am. J. Enol. Vitic. 52, $1-7$.

Cabrita, L., Fossen, T. \& Andersen, Ø.M., 2000. Colour and stability of the six common anthocyanin-3-glucosides in aqueous solutions. Food Chem. 68, 101107.

Crippen, D.D. \& Morrison, J.-C., 1986. The effects of sun exposure on the phenolic content of Cabernet Sauvignon berries during development. Am. J. Enol. Vitic. 37, 243-247

De Beer, D., Joubert, E., Gelderblom, W.C.A. \& Manley, M., 2003. Antioxidant activity of South African red and white cultivar wines: Free radical scavenging. J. Agric. Food Chem. 51, 902-909.

De Beer, D., Joubert, E., Marais, J. \& Manley, M., 2006. Unravelling the total antioxidant capacity of Pinotage wines: Contribution of phenolic compounds. J. Agric. Food Chem. 54, 2897-2905.

De Villiers, F.S., Schmidt, A., Theron, J.C.D. \& Taljaard, R., 1996. Onderverdeling van die Wes-Kaapse wynbougebiede volgens bestaande klimaatskriteria. Wynboer 78, 10-12.

Downey, M.O., Harvey, J.S. \& Robinson, S.P., 2004. The effect of bunch shading on berry development and flavonoid accumulation in Shiraz grapes. Aust. J. Grape Wine Res. 10, 55-73.

Eagerman, B.A., Clydesdale, F.M. \& Francis, F.J., 1973. Comparison of color scales for dark colored beverages. J. Food Sci. 38, 1051-1055.

Giusti, M.M., Rodríguez-Saona, L.E. \& Wrolstad, R.E., 1999. Molar absorptivity and color characteristics of acylated and non-acylated pelargonidin-based anthocyanins. J. Agric. Food Chem. 47, 4631-4637.

Gonnet, J.-F., 1999. Colour effects of co-pigmentation of anthocyanins revisited 2. A colorimetric look at the solutions of cyanin co-pigmented by rutin using the CIELAB scale. Food Chem. 66, 387-394

Haselgrove, L., Botting, D., Van Heeswijk, R., Høj, P., Dry, P.R., Ford, C. \& Iland, P., 2000. Canopy microclimate and berry composition: The effect of bunch exposure on the phenolic composition of Vitis vinifera L. cv. Shiraz grape berries. Aust. J. Grape Wine Res. 6, 141-149. 
Heredia, F.J., Francia-Aricha, E.M., Rivas-Gonzalo, J.C., Vicario, I.M. \& SantosBuelga, C., 1998. Chromatic characterization of anthocyanins from red grapes I. pH effect. Food Chem. 63, 491-498.

Huglin, P., 1986. Biologie et écologie de la vigne. Editions Payot, Lausanne, París.

Hunter, J.J., 1999. Present status and prospects of winegrape viticulture in South Africa. In: Proc. 11th Meeting Study Group for Vine Training Systems, June 1999, Marsala, Sicily, Italy. pp. 70-85.

Jackson, D.I. \& Lombard, P.B., 1993. Environmental and management practices affecting grape composition and wine quality - A review. Am. J. Enol. Vitic. 44, 409-430.

Kliewer, W.M., 1970. Effect of day temperature and light intensity on coloration of Vitis vinifera L. grapes. J. Am. Soc. Hort. Sci. 95, 693-697.

Landrault, N., Poucheret, P., Ravel, P., Gasc, F., Cros, G. \& Teissedre, P.-L., 2001. Antioxidant capacities and phenolics levels of French wines from different varieties and vintages. J. Agric. Food Chem. 49, 3341-3348.

Le Roux, E.G., 1974. A climatic division of the South West-Cape wine regions (in Afrikaans). M.Sc. thesis, University of Stellenbosch, Private Bag X1, Matieland 7602, South Africa.

Mateus, N., Machado, J.M., De Freitas, V., 2002. Development changes of anthocyanins in Vitis vinifera grapes grown in the Douro valley and concentration in respective wines. J. Sci. Food Agric. 82, 1689-1695.

Mateus, N., Marques, S., Gonçalves, A. C., Machado, J. M., De Freitas, V., 2001. Proanthocyanidin composition of red Vitis vinifera varieties from the Douro valley during ripening: Influence of cultivation altitude. Am. J. Enol. Vitic. 52, 115-121.

McMurrough, I. \& McDowell, I., 1978. Chromatographic separation and automated analysis of flavonols. Anal. Biochem. 91, 92-100.

Miguel-Tabares, J.A., Martin-Luis, B., Carrillo-Lopez, M., Diaz-Diaz, E. \& Darias-Martin, J., 2002. Effect of altitude on the wine-making potential of Listan Negro and Ruby Cabernet cultivars in the south of Tenerife island. J. Int. Sci. Vigne Vin 36, 185-194.
Mori, K., Saito, H., Goto-Yamamoto, N., Kitayama, M., Kodayashi, S., Sugaya, S., Gemma, H. \& Hashizume, K., 2005. Effects of abscisic acid treatment and night temperatures on anthocyanin composition in Pinot noir grapes. Vitis 44, 161-165.

Peng, Z., Iland, P., Oberholster, A., Sefton, M.A. \& Waters, E.J., 2002. Analysis of pigmented polymers in red wine by reversed phase HPLC. Aust. J. Grape Wine Res. 8, 70-75.

Re, R., Pellegrini, N., Proteggente, A., Pannala, A., Yang, M. \& Rice-Evans, C.A., 1999. Antioxidant activity applying a improved ABTS radical cation decolorization assay. Free Radic. Biol. Med. 26, 1231-1237.

Reynolds, A.G., Pool, R.M. \& Mattick, L.R., 1986. Influence of cluster exposure on fruit composition and wine quality of Seyval blanc grapes. Vitis 25, 85-95.

Ribéreau-Gayon, P. \& Stonestreet, E., 1965. Le dosage des anthocyanes dans les vins rouges. Bull. Soc. Chim. 9, 2649-2652.

Singleton, V.L. \& Rossi, J.R., 1965. Colorimetry of total phenols with phosphomolybdic-phosphotungstic acid reagents. Am. J. Enol. Vitic. 16, 144-158.

Smart, R.E. \& Dry, P.R., 1980. A climatic classification for Australian viticultural regions. Aust. Grapegrower Winemaker 196, 8-16.

Smart, R. \& Robinson, M., 1991. Sunlight into wine: a handbook for winegrape canopy management. Winetitles, Underdale, Australia.

Spayd, S.E., Tarara, J.M., Mee, D.L. \& Ferguson, J.C., 2002. Separation of sunlight and temperature effects on the composition of Vitis vinifera cv. Merlot berries. Am. J. Enol. Vitic. 53, 171-182.

Tamborra, P., Esti, M., Minafra, M. \& Sinesio, F., 2003. Phenolic compounds in red-berry skins of Uva di Troia and Bombino nero grapes (Vitis vinifera L.). Ital. J. Food Sci. 15, 347-357.

Wolf, T.K., Dry, P.R., Iland, P.G., Botting, D., Dick, J., Kennedy, U. \& Ristic, R., 2003. Response of Shiraz grapevines to five different training systems in the Barossa valley, Australia. Aust. J. Grape Wine Res. 9, 82-95. 